\title{
VIYYANA SATIM ANTLAŞMASI'NA (CISG) GÖRE ALICININ SÖZLEŞMEYİ İHLÂLİ HALİNDE SATICININ HAKLARI
}

\author{
Arş. Gör. Furkan Güven TAŞTAN*
}

\begin{abstract}
ÖZET
Çalışmamızda sözleşmenin alıcı tarafından ihlâli hâlinde satıcının sahip olduğu haklar meselesi ele alınmaktadır. Bu kapsamda ilk olarak alıcının asli yükümlülükleri olan semen ödeme ve malı teslim alma ile diğer yükümlülüklerine yer verilmiştir. Söz konusu yükümlülüklerin ihlâlinin doğuracağı sonuçlar bakımından ihlâl; esaslı ihlâl ve esaslı olmayan ihlâl şeklinde iki dereceye ayrılmış ve satıcının alıcıya ek süre tanımasının bu derecelendirmeye tesiri üzerinde durulmuştur.

Alıcının sözleşmeyi ihlâlinden bahsedebilmek için bir yükümlülüğü ihlâl etmiş olması ve sorumluluktan kurtulmamış olması şartlarının bir arada bulunması gerekir. Sözleşmenin ihlâli halinde satıcının sahip olduğu hakların incelendiği son bölümde, aynen ifayı talep etme, sözleşmeyi ortadan kaldırma ve tazminat talep etme haklarına yer verilmiştir. Dönme kavramı yerine sözleşmeyi ortadan kaldırma ifadesinin neden tercih edildiğinin açıklandığı bu bölümde, son olarak Antlaşma'da sözleşmenin alıcı tarafından ihlâli halinde satıcı lehine öngörülmüş özel bazı durumlar incelenmiş ve çalışma sonlandırılmıştır.
\end{abstract}

Anahtar Kelimeler: Viyana Satım Antlaşması, CISG, Sözleşmenin İhlali, Satıcının Hakları, Sözleşmeyi Ortadan Kaldırma Hakkı, Esaslı İhlâl, Ek Süre.

* $\quad$ Ankara Yıldırım Beyazıt Üniversitesi Hukuk Fakültesi, Medenî Hukuk Anabilim Dalı, fgtastan@ybu.edu.tr (Geliş Tarihi: 29.06.2018 - Kabul Tarihi: 02.10.2018). 


\title{
SELLER'S REMEDIES AGAINST BREACH OF CONTRACT BY THE BUYER UNDER THE VIENNA CONVENTION ON THE INTERNATIONAL SALE OF GOODS
}

\begin{abstract}
This article is about remedies of the Seller in the event of a breach of contract by the buyer. In this scope, firstly the buyer's main obligations and other obligations have examined. In respect of the consequences of that obligations, the breach has separated into two degrees as fundamental and non-fundamental breach and the effect of the additional period of time to rating has examined.

For the breach of contract by the buyer, he has to violate an obligation and not being released from the responsibility. In the case of breach of the contract, remedies of the seller that includes as a right to require the buyer to perform his obligations, right to declare the contract avoided and right to compensate of the seller has examined in the last chapter. This chapter also explains why the phrase "right to declare the contract avoided" is preferred rather than the phrase "right of rescission". Finally, this article was concluded by examining specific rights of the seller in case of the buyer has been violated the contract according to CISG.
\end{abstract}

Key Words: Vienna Convention on the International Sale of Goods, CISG, Breach of Contract, Remedies of Seller, Right to Declare the Contract Avoided, Fundamental Breach, Additional Period of Time. 


\section{GİRiş}

1928'de Rabel tarafindan ortaya atılan "dünya satım hukuku”nun oluşturulması fikrinden hareket edilerek hazırlanan Milletlerarası Mal Satımına İlişskin Sözleşmeler Hakkında Birleşmiş Milletler Antlaşması ("CISG", "Viyana Sattm Antlaşması" ya da "Antlaşma"1), günümüzde milletlerarası ticaretin "Magna Carta"sı olma yolunda ilerlemektedir². Türkiye, Antlaşma'yı 7.7.2010 tarihinde kabul etmiş; Antlaşma Türk Hukukunda 1.8.2011 tarihinde yürürlüğe girmiştir ${ }^{3}$.

Viyana Satım Antlaşması'nda alıcının yükümlülükleri; semenin ödenmesi, malın teslim alınması ve diğer yükümlülükler olarak belirtilmiştir. Çalışmamızda bu yükümlülükler ve yükümlülüklerin ihlâline bağlanan sonuçlar çerçevesinde aşağıdaki problemlere çözüm aranmaya çalş̧ılmaktadır.

Alıcının yükümlülüklerinin ihlâli konusunda değinilmesi gereken ilk husus, alııının yükümlülüklerini yerine getirmemesi hâlinde satıcının hangi haklara sahip olduğudur. Bu noktada Antlaşma, acaba Türk/İsviçre hukukundaki gibi ihlâlin türünü mü (temerrüt, kötü ifa, imkânsizllk gibi), yoksa ihlâlin derecesini mi (esaslı bir ihlâl olup olmadiğı) dikkate almaktadır?

Alıcının yükümlülüklerini ihlâl etmesine dair problemlerden bir diğeri de asli - diğer yükümlülükler ayrımıla esaslı - esaslı olmayan ihlâl ayrımının örtüşüp örtüşmediğidir. Yani her zaman asli yükümlülüklerin ihlâli durumunda esaslı ihlâl; diğer yükümlülüklerin ihlâlinde ise esaslı olmayan bir ihlâlden söz edilebilir mi?

\footnotetext{
"Milletlerarası Mal Satımına İlişkin Sözleşmeler Hakkında Birleşmiş Milletler Antlaşması" ifadesinin uzunluğu sebebiyle çalışmamızda bunun yerine "CISG", "Viyana Satım Antlaşmasi" ya da "Antlaşma" terimleri kullanılacaktır. Aksi belirtilmedikçe "sözleşme" teriminden anlaşılması gereken ise tarafların mal satımına ilişkin aralarında gerçekleştirdiği akittir.

2 Hazırlanış aşamasında Viyana Satım Antlaşması'nın kapsayıcı ve uluslararası niteliğine önem verilmiştir. Akipek Öcal, Şebnem; 'Türk Hukuku Açısından Viyana Satım Sözleşmesi': Temel, Erhan (Editör) (2015) Viyana Satım Sözleşmesi Hukuku ve Tüketici Hukuku, Ankara, Adalet, s. 94; Karollus, Martin (1995) 'Judicial Interpretation and Application of the CISG in Germany 1988-1994' Cornell Review of the Convention on Contracts for the International Sale of Goods, s. 77

3 RG 07.04.2010, sayı 27545.
} 
Satıc1, alıcıya yerine getirmediği yükümlülüklerini ifa etmesi için makul uzunlukta bir ek süre tanıyabilir. Sürenin sonuçsuz kalması durumunda satıcı, Antlaşma’ya göre doğrudan sözleşmeyi ortadan kaldırma hakkını kullanabilmektedir. Bu durumda ek süre müessesi, ihlâlin derecesine doğrudan tesir ederek esaslı olmayan bir ihlâli, esaslı bir ihlâle mi dönüştürmektedir?

Satıcıya tanınan en önemli imkân olan ve Antlaşma'nın orijinal metninde "avoidance", resmî Türkçe çevirisinde ise "sözleşmeyi ortadan kaldırma hakkı" olarak ifade edilen terim, çevirideki hâliyle korunarak mı yoksa "dönme hakkı" şeklinde mi kullanılmalıdır? Söz ve söze yüklenen anlamın son derece önem arz ettiği bir dal olan hukukta, bir kavramın şartları, sınırları ve sonuçlarının eksiksiz bir biçimde tespit edilebilmesi için terminoloji probleminin çözülmesi elzemdir.

Çalışmamızda incelenen problemlerden sonuncusu ise, doktrinde sözleşmeyi ortadan kaldırma hakkının sınırları başlığı altında ifade edilen geç ifa durumunun, hakikaten bu hakkın bir sınırlamasını mı; yoksa aksine zaman bakımından genişletilmesi hâlini mi oluşturduğu yönündedir.

Soru işaretiyle noktalanan bu hususların sağlıklı bir biçimde değerlendirilebilmesi amacıyla alıcının yükümlülükleri ve yükümlülüklerin ihlâl edilmesinin sonuçları konusunda genel açıklamalar yapılmış; bu genel açıklamalar içerisinde anılan problemler sırasıyla alt başlıklar içerisinde çözümlenmeye çalışılmıştır.

\section{I.ALICININ YÜKÜMLÜLÜKLERİ}

Viyana Satım Antlaşması'nda (“CISG” ya da "Antlaşma”) açıkça ifade edilmemekle birlikte, alıcının yükümlülükleri asli yükümlülükler ve diğer yükümlülükler olarak ikiye ayrılmaktadır. Semen ödeme ve malı teslim alma yükümlülüğü olarak ifade edilebilecek alıcının asli yükümlülükleri, CISG m. 53 ilâ 60. maddelerde düzenlenmiştir. Diğer yükümlülükler ise dürüstlük kuralından, ticari teamüllerden ve tarafların anlaşmasından doğmakta olup bu yükümlülüklerin ihlâlinin de sözleşmenin ihlâli sonucu doğuracağı hususu CISG m. 62'de yer almaktadır. 
Viyana Satım Antlaşması'nda alıcının yükümlülüklerinin ihlâli, satıcının yükümlülüklerinin ihlâline oranla daha sade bir yapıdadır. Öyle ki, satıcının sözleşmeye aykırı davranışı, imkânsızlık, ayıplı ifa, zamanında ifa etmeme ve eksik ifa gibi çok çeşitli bir yapıda bulunmaktadır. Buna karşılık alıcının sözleşmeyi ihlâl etmesi temel olarak semenin ödenmemesi, malın teslim alınmaması ve diğer yükümlülüklerin ihlâlinden kaynaklanır"

Satıcının sözleşmeyi ihlâl etmesinde olduğu gibi, alıcının ihlâli halinde de ihlâl edilen yükümlülügün asli yahut diğer yükümlülük olmasının bir önemi bulunmamakta; sözleşmenin ihlâline ilişkin sonuçlar ortaya çıkmaktadır. Bu kapsamda, sırasıyla alıcının anılan yükümlülükleri incelenecektir.

\section{A. SEMEN ÖDEME YÜKÜMLÜLÜĞÜ}

Semen, alıcının satıcının edimi karşılığında ödemeyi taahhüt ettiği, para borcundan oluşan bir edimi ifade eder. Semenin, para borcu olma zorunluluğu taraflar arasındaki sözleşme ilişkisini, trampa sözleşmesinden ayırmaktadır. Semenin ödenmesi, alıcının anlaşılan miktarı, hiçbir sınırlama olmaksızın satıcının tasarrufuna sunması anlamına gelir 5 .

Alıcının en önemli borcu olan ${ }^{6}$ semen ödeme yükümlülüğü, CISG m. 54 ilâ 59'da düzenlenmiştir. Tamamlayıcı nitelikteki bu hükümler, ancak tarafların semenin ödenmesine ilişkin aksine bir anlaşmaya varmamaları hâlinde uygulama alanı bulmaktadır.

Taraflar semen miktarını açıkça belirleyecekleri gibi, örtülü olarak da kararlaştırabilirler7. Semenin hangi para birimiyle ödeneceği konusunda Antlaşma'da herhangi bir düzenleme yapılmamıştır. Taraflar, sözleşmede

Knapp, Victor 'Article 61-65' : Bianca-Bonell (Editör) (1987) Commentary on the International Sales Law, Milan, s. 444.

5 Zeytin, Zafer (2015) Milletlerarası Satım Sözleşmeleri Hukuku- CISG, 2. Baskı, Ankara, Seçkin, s. 232.

6 Schwenzer/Schlechtriem (2015) Milletlerarası Mal Satımına İlişkin Sözleşmeler Hakkında Birleşmiş Milletler Antlaşması (Viyana Satım Sözleşmesi) Şerhi, İstanbul, On İki Levha, s. 1021.

7 Kaya, Cansu (2012) CISG Gereğince Alıcının Satım Bedelini Ödeme Borcu, İstanbul, On İki Levha, s. 62 ve 66 . Taraflar semenin kapsamını CIF, FOB ve benzeri uluslararası ticari terimlere atıf yapmak suretiyle de belirleyebilirler (Zeytin, s. 230). 
buna ilişkin bir husus kararlaştırmazlarsa, mesele taraflar arasındaki alışkanlıklara ya da ticari teamüllere uygun şekilde çözülecektir. Bu yoldan da bir sonuç alınamaması hâlinde, problem CISG m. 7/II hükmüne göre Antlaşma'nın temelinde yatan genel ilkelere; bu ilkelerden de netice elde edilememesi halinde kanunlar ihtilafı kuralları uyarınca uygulanması gereken hukuka göre çözümlenir. Doktrindeki hâkim görüş, Viyana Satım Antlaşması'nın ruhuna uygun bir şekilde, yeknesak bir uygulamanın geliştirilmesi amacıyla kanunlar ihtilafı kurallarına başvurulmadan, semenin satıcının işyerinin bulunduğu ülkenin para birimiyle ödenmesi gerektiği yönündedir

\section{B. MALI TESLIM ALMA YÜKÜMLÜLÜĞÜ}

Alıcının malı teslim alma yükümlülüğü, malın teslim alınması amacıyla yapılacak hazırlık fiillerinden ve malın fiilen teslim alınmasından oluşmaktadır. Alıcının gerçekleştirmekle yükümlü olduğu hazırlık fiilleri, kendisinden makul olarak beklenen her türlü davranışı kapsar (CISG m. 60) ${ }^{9}$. Bu fiiller, tarafların anlaşması, taraflar arasındaki uygulama ve ticari teamüllerle tespit edilmektedir ${ }^{10}$. Örneğin teslimin satıcının işyerinde yapılacağının kararlaştırılması durumunda, alıcının gerekli ithalat izinlerini alması gerekir. Teslimin alıcının işyerinde yapılacağı durumlarda ise, alıcının teslim edilecek mallara uygun şekilde depo imkânını sağlaması, hazırlık fiilleri kapsamında değerlendirilir.

Malın fiilen teslim alınması, alıcının kararlaştırılan yer ve zamanda ${ }^{11}$, hiçbir sınırlama olmaksızın kendisinin tasarrufuna sunulan malı fiilen dev-

Zeytin, s. 230.

9 Sevon, Leif (1990) 'Obligations of the Buyer under the Vienna Convention on the International Sale of Goods' Suomalainen Lakimiesten Yhdistys: - Tidskrift utgiven av Juridiska Föreningen i Finland, Cilt 126, s. 231.

10 Taraflar arasındaki sözleşmede uluslararası ticari terimlere atıf yapılmasıyla, alıcının teslim alma borcunun kapsamı belirlenebilir (Sert, Selin (2013) Viyana Satım Sözleşmesinde (CISG) İfa Engelleri ve Sonuçları, İstanbul, Vedat, s. 156; Zeytin, s. 243). Öte yandan, alıcının teslime yönelik hazırlık çalışmaları, objektif bir değerlendirmeyle makul olarak alıcıdan beklenen her türlü davranışı kapsar (Zeytin, s. 243).

11 Alıcının malı teslim alma yükümlülüğü, satıcının malı teslim etme borcunun karşılığını oluşturmaktadır. Bu doğrultuda malın teslim yeri CISG m. 31'de; teslim zamanı ise CISG m. 33’te düzenlenmiştir. 
ralması anlamına gelmektedir. Çoğu zaman tarafların uluslararası ticari terimlere yaptığ 1 atıflar doğrultusunda, malı temsil eden belgelerin alınması, malın devralınması sonucunu doğurmaktadır ${ }^{12}$. Alıcı, kural olarak malı teslim alma yükümlülüğü altında olmakla birlikte, belirlenen vadeden önce teslim yapılması hâlinde ya da anlaşılandan daha fazla miktarda mal teslim edilmesi durumlarında ifayı reddedebilir (CISG m. 52).

\section{DİĞER YÜKÜMLÜLÜKLERI}

Alıcının diğer yükümlülüklerini yerine getirmemesi de CISG m. 62 gereğince sözleşmenin ihlâli sonucunu doğurmaktadır. Diğer yükümlülükler; Antlaşma'dan, sözleşmeden, tarafların alışkanlıklarından veya ticari teamüllerden kaynaklanmaktadır. Bu yükümlülükler, bünyesinde ağırlıklı olarak asli yükümlülüklerin yerine getirilmesine hizmet eden yan yükümlülükleri ihtiva eder. Antlaşma'dan kaynaklanan diğer yükümlülüklere; CISG m. 65 uyarınca alıcının malın niteliğini belirleme yükümlülüğü, CISG m. 86 uyarınca malın muhafazasını sağlama yükümlülüğü ve CISG m. 88 uyarınca çabuk bozulabilen malları satma yükümlülüğü örnek gösterilebilir ${ }^{13}$. Diğer yükümlülüklerin sözleşmeyle belirlenmesi durumlarına ise sadece belirtilen ülkelere dağıtım ve satış yapma, satış için teknik bilgi sağlama, kullanma talimatlarına ve ithalatihracat yasaklarına uyma durumları örnek verilebilir.

Doktrinde bazı yazarlar, muayene ve ihbar külfetleri ile satıcının sözleşmeyi ihlâl etmesi hâlinde zararı onun lehine azaltma külfetini de alıcının diğer yükümlülükleri çerçevesinde ele almaktadır ${ }^{14}$. Ancak külfetler, nitelikleri itibariyle alıcıya teknik anlamda bir yükümlülük yüklemeyen davranış modellerinden oluşmaktadır ${ }^{15}$. Antlaşma kapsamında külfetlerin yerine getirilmemesi, yalnızca elde edilmesi mümkün olan hakların kazanılamaması sonucunu doğurmakta, bunun ötesinde yükümlülüğün ihlâline ise sebep olmamaktadır. Dolayısıyla, külfetlerin diğer yükümlülükler başlı̆̆ı altında incelenmesi kanaatimizce isabetsizdir.

\footnotetext{
Zeytin, s. 243.

13 Kanışlı, Erhan (2013) CISG Uyarınca Alıcının Yükümlülükleri ve Sözleşmeye Aykırılık Halinde Satıcının Hakları, İstanbul, On İki Levha, s. 40; Sert, s. 159-160.

14 Kanışlı (2013), s. 37, 38 ve 42.

15 Eren, Fikret (2017) Borçlar Hukuku Genel Hükümler, 21. Baskı, Ankara, Yetkin, s. 45.
} 


\section{ALICININ YÜKÜMLÜLÜKLERINII İHLÂL ETMESİ}

Viyana Satım Antlaşması, ifa engellerine Kara Avrupası hukuk sisteminden farklı bir tarzda bütüncül bir bakış açısıyla yaklaşmış ve tüm ifa engellerini sözleşmenin ihlâli (breach of contract) kavramı çatısı altında toplamıştır. Dolayısıyla içerisinde Türk/İsviçre hukuk sisteminin de bulunduğu Kara Avrupası hukuk sisteminde çok çeşitli hallerde bulunan ifa engelleri müessesesi, Viyana Satım Antlaşması̀nda Anglosakson hukuk sistemine yaklaştırılmak suretiyle tek bir kavram altında birleştirilmiştir ${ }^{16}$.

Viyana Satım Antlaşması kapsamında taraflardan birinin sözleşmeyi ihlâl etmesi durumunda hangi hakların kullanılacağının tespitinde; ihlâlin türü değil, derecesi dikkate alınmakta ve sözleşmenin esaslı şekilde ihlâl edilmesiyle esaslı olmayan şekilde ihlâl edilmesi, özellikle sözleşmeyi ortadan kaldırma hakkı bakımından farklı sonuçlara tâbi tutulmaktadır. Öyle ki esaslı ihlâl halinde ihlâle dayanan taraf, aynen ifa ve tazminat taleplerinin dışında doğrudan sözleşmeyi ortadan kaldırma hakkına da sahip olmaktadır. Bu kapsamda sırasıyla alıcının yükümlülüklerini ihlâlinin dereceleri ve ihlâlin şartları incelenecektir.

16 Kara Avrupası hukuk sistemindeki bu yaklaşıma "cause-orianted approach"; Anglosakson sistemindeki yaklaşıma ise "breach of contract approach" ya da "remedy approach" denilmektedir. Schwenzer'e göre bu iki yaklaşım, uluslararası satım hukukunun yeknesaklaştırılması amacıyla "modern approach" çatısı altında birleştirilmiştir. Söz konusu modern yaklaşımla birlikte, Anglosakson sistemindeki sözleşmeye aykırılık yaklaşımı, Antlaşma'ya taraf olan ve Kara Avrupası hukuk sistemine tâbi ülkelerin bulunması sebebiyle "civil law" lehine törpülenmiştir. Öyle ki "common law" sisteminde sözleşmeden dönmek daha zor ve belirli kısıtlamalara tâbiyken, modern yaklaşımla birlikte, esaslı ihlâlin bulunması durumunda sözleşmeyi ortadan kaldırmak görece daha kolaylaştırılmıştır. Bu da ifa engellerine bakışın "civil law”a yaklaştırıldığını gösterir. Kanışıl, Erhan; 'CISG Uyarınca Alıcının Sözleşmeye Aykırılığı Halinde Satıcının Hakları' : Okur, Sinan (Editör) (2016) Milletlerarası Mal Satım Hukuku, Ankara, Adalet, s. 472; Sarıkaya, Murat (2017) CISG Kapsamında Sözleşmenin Esaslı İhlali, İstanbul, Filiz, s. 9. CISG'ın ifa engellerine sistemine ilişkin tarihi arka plan hakkında detaylı bilgi için bkz. Atamer, Yeşim (2008) Satıcının Sözleşmeye Aykırı Davranışı Ekseninde CISG’ın İfa Engelleri Sistemine Genel Bakış: Milletlerarası Satım Hukuku, İstanbul, On İki Levha, s. 224 vd.; Dayığlu, Yavuz (2011) CISG Uygulamasında Sözleşmenin İhlali Halinde Alıcının Hakları ve Özellikle Alıcının Tazminat Talep Etme Hakkı, İstanbul, On İki Levha, s. 31. 


\section{A. İHLÂLIN DERECELER I ${ }^{17}$}

\section{Esaslı İhlâl}

Alıcının sözleşmeden kaynaklanan yükümlülüklerini ihlâlinin derecesinin tespitinde, tıpkı satıcıda olduğu gibi CISG m. 25 hükmüne başvurulmaktadır ${ }^{18}$. Anılan hükme göre alıcının yükümlülüklerini ihlâlinin, esaslı bir ihlâl teşkil etmesi için; (a) yükümlülüğe aykırı davranışın, yani ihlâlin bulunması, (b) ihlâlin satıcıda önemli bir menfaat kaybına sebep olması ve (c) menfaat kaybına ilişkin sonucun, alıcı ve alıcıyla aynı şartlar içindeki makul kişiler tarafından öngörülebilmesi şartlarının bir arada bulunması gerekir.

(a) Sözleşmenin alıcı tarafından esaslı ihlâl edilebilmesinden bahsedebilmek için öncelikle taraflar arasındaki sözleşmeden kaynaklanan bir yükümlülügün ihlâl edilmiş olması gerekir ${ }^{19}$. Zirâ ihlâl olmadan, esaslı ihlâlden bahsedilemeyecektir.

(b) İhlâlin satıcı nezdinde önemli bir menfaat kaybına sebep olması da, esaslı ihlâl için aranan şartlardan bir diğeridir. Önemli menfaat kaybı, meydana gelen ihlâlin satıcı nezdinde, kendisinin beklediği şeyden önemli

17 Hem esaslı olmayan hem de esaslı ihlâlin sözleşmenin ihlâli çatısı altında değerlendirilmesi sebebiyle, bu iki kavramın birbirinden ayırt edilmesinde "tür" ya da "çeşit" ifadelerinin kullanılmasının isabetli olmadığını düşünmekteyiz. Zirâ Antlaşma; ifa engelleri müessesesini öncelikle "sözleşmenin ihlâli" kavramı çatısında bir araya getirmiş ve ardından kanaatimizce ihlâli derecelerine ayırmıştır. Bu nedenle çalışmamızda, esaslı olmayan ihlâl ile esaslı ihlâlin birbirinden ayırt edilmesinde "derece" ifadesi tercih edilmiştir. Nitekim Knapp de bu iki kavramın birbirinden ayırt edilmesinde, ihlâlin niteliği ("quality of the buyer's breach") kriterine başvurmaktadır. Knapp, s. 444. "Derece" ifadesinin Knapp'in tercih ettiği "quality" kavramını karşılayacağı kanaatindeyiz.

18 Duncan, John C. (2000) 'Nachfrist Was Ist? Thinking Globally and Acting Locally: Considering Time Extension Principles of the U.N. Convention on Contracts for the International Sale of Goods in Revising the Uniform Commercial Code' Brigham Young Law Review, s. 1380; Erdem, Ercüment (2013) 'Viyana Satım Antlaşması'na Göre Alıcı ve Satıcının Borçlarının İhlalinin Sonuçları ve Türk Hukuku ile Karşılaştırılması’ Galatasaray Üniversitesi Hukuk Fakültesi Dergisi, Sayı: 1, s. 272; Yılmaz, Süleyman (2013) Milletlerarası Mal Satımına İlişkin Sözleşmeler Hakkında Birleşmiş Milletler Antlaşması (CISG) Uyarınca Sözleşmenin İhlali Halinde Alıcının Hakları, Ankara, Yetkin, s. 90.

19 Atamer, s. 238; Koch, Robert (1998) 'The Concept of Fundamental Breach of Contract under the United Nations Convention on Contracts for the International Sale of Goods (CISG)' Pace Review of the Convention on Contracts for the International Sale of Goods, s. 262; Yelkenci, Işıl (2014) Milletlerarası Mal Satımına İlişkin Sözleşmeler Hakkında Birleşmiş Milletler Antlaşması (CISG) Uyarınca Alıcının Sözleşmeden Dönmesi, İstanbul, On İki Levha, s. 35; Yılmaz, s. 91. 
ölçüde yoksun kalması neticesini doğuran olumsuz sonuçları ifade eder ${ }^{20}$. Satıcının beklediği şeyden kastedilen, satıcının ulaşmak istediği sonuçlar değil; yalnızca onun akdî menfaatleri, yani sözleşmenin tarafı olması nedeniyle beklediği menfaatlerdir. Önemli menfaat kaybı; CISG m. 74’te düzenlenen tazminat sorumluluğu kapsamındaki zarar kavramından da farklıdır ${ }^{21}$.

Neticede ihlâl nedeniyle satıcı, beklediği menfaatten yoksun kalmış ya da sözleşme onun için artık anlamsız bir hâle gelmişse, önemli menfaat kaybına ilişkin şart da gerçekleşmiştir. Taraflar, yaptıkları sözleşmede hangi yükümlülüklerin ihlâl edilmesinin esaslı ihlâle sebebiyet vereceğini açı ya da örtülü olarak kararlaştırabilir. Böyle bir kararlaştırmanın olmaması durumunda, hangi yükümlülüklerin ihlâlinin esaslı sayılacağı, somut olayın şartlarına bakılarak ve CISG m. 8 uyarınca sözleşme yorumlanarak belirlenir.

(c) Son olarak esaslı ihlâl için, satıcı nezdinde meydana gelen önemli menfaat kaybının doğurduğu sonuçların öngörülebilir olması gerekir. Öngörülebilirlik, bu sonuçların alıcı ve alıcıyla aynı şartlar altında bulunan makul kişiler tarafından öngörülebilmesini ifade eder $^{22}$. Öngörülebilirliğin hangi anda bulunması gerektiğine ilişkin olarak doktrinde, ihlâlin yapıldığ 1 an ve sözleşmenin kurulduğu an gibi çeşitli görüşler ileri sürülse de, kanaatimizce sözleşmenin kurulduğu anın dikkate alınması gerekir ${ }^{23}$.

Satıcı, alıcının sözleşmeyi esaslı olarak ihlâl ettiğini ispatla yükümlüdür. Buna karşılık önemli menfaat kaybının öngörülemez olduğunu ispat

20 Atamer, s. 239; Erdem, s. 273; Sarıkaya, s. 115; Toker, Ali Emrah (2014) 'Viyana Satım Sözleşmesi (CISG) Uyarınca Sözleşmenin Esaslı İhlâli’ Milletlerarası Hukuk ve Milletlerarası Özel Hukuk Bülteni, Cilt: 33, Sayı: 1, s. 226; Yelkenci, s. 42-43; Yılmaz, s. 92. Antlaşma'da önemli menfaat kavramı tanımlanmamıştır. Koch, s. 262-263. İhlal, satıcının sözleşmeden beklediği objektif menfaatin kaybolmasına yol açıyorsa, ihlâlin esaslı olduğu sonucuna varılabilir. Zeytin, s. 256. OLG Brandenburg, 18 Kasım 2008, CISG-Online 1734: Satıcının sözleşmeden beklediği menfaatin ne olduğu, her somut olay açısından ayrı ayrı değerlendirilmelidir.

${ }^{21}$ Atamer, s. 239; Sert, s. 74; Yelkenci, s. 40.

22 Sert, s. 70; Yılmaz, s. 94. Öngörülebilirlik şartının sübjektif ve objektif değerlendirmesine ilişkin bilgi için bkz. Atamer, s. 243; Koch, s. 265; Sarıkaya, s. 141 vd.; Yelkenci, s. 44 vd.

23 İleri sürülen diğer görüşler hakkında ayrıntılı bilgi için bkz. Flechtner, Harry M. (1988) 'Remedies Under the New International Sales Convention: The Perspective from Article 2 of the U.C.C.' Journal of Law and Commerce, Cilt 8, s. 76; Sarıkaya, s. 155; Sert, s. 72; Yılmaz, s. 94-95. 
yükü ise alıcıya aittir. Alıcının bu durumu ispatlaması hâlinde esaslı ihlâlden bahsedilemeyecektir. ${ }^{24}$

Alıcının yükümlülükleri açısından yapılan asli yükümlülükler ve diğer yükümlülükler ayrımı; esaslı ihlâl ve esaslı olmayan ihlâl kavramlarıyla örtüşmemektedir. Yâni asli yükümlülüğün ihlâli her zaman için esaslı ihlâle vücut vermeyeceği gibi, kimi zaman diğer yükümlülüklerin ihlâli esaslı ihlâl teşkil edebilir. Anılan yükümlülüklerin esaslı bir ihlâl oluşturup oluşturmadığı meselesi, esaslı ihlâl müessesesinin şartları açısından her somut olayda ayrıntısıyla değerlendirilmelidir ${ }^{25}$.

\section{Esaslı Olmayan İhlâl}

Esaslı ihlâlin şartlarından birini taşımayan ihlâllerin tamamı, esaslı olmayan ihlâle vücut vermektedir. Asli veya diğer yükümlülüklerin esaslı olmayan şekilde ihlâli halinde, satıcının sözleşmenin ortadan kaldırılması dışındaki diğer haklarını -örneğin aynen ifa ve tazminat talebinde bulunma hakkı- kullanması mümkündür.

\section{Alıcıya Ek Süre Verilmesinin İhlâlin Derecesine Tesiri}

Esaslı olmayan ihlâlden farklı olarak esaslı ihlâlde satıcı, doğrudan sözleşmeyi ortadan kaldırma hakkına sahiptir. Bu imkân, kural olarak esaslı olmayan ihlâller açısından söz konusu değildir. Ancak esaslı olmayan bazı ihlâl durumlarında da, ek süre tanımak suretiyle sözleşmenin ortadan kaldırılması mümkündür. Esaslı olmayan ihlâl, böylelikle alıcıya ek süre tanınarak "adeta" esaslı bir ihlâle dönüştürülmektedir ${ }^{26}$. En azından ek süre tanımak suretiyle, ihlâlin esaslı olup olmadığı hususundaki belirsizlik giderilerek $^{27}$ sözleşmeyi ortadan kaldırma hakkı tereddütsüz bir şekilde

24 Schwenzer/Schlechtriem, s. 566-567.

25 Sarıkaya, s. 191; Toker, s. 243.

26 Önemle ifade etmek gerekir ki, kanaatimizce ek sürenin verilmesi, esaslı olmayan ihlâli, teknik anlamda esaslı ihlâle dönüştürmez. Nitekim CISG'nin sistematiği ve lafzı da bu yoruma uygun yapıdadır. Öyle ki, CISG m. 64'te ek süre verilmesiyle, ihlâlin esaslı ihlâle dönüşeceğinden bahsetmemiş; yalnızca belirli şartların varlığı hâlinde sözleşmeyi ortadan kaldırma imkânına sahip olduğu hükme bağlanmıştır. Esaslı ihlâlin belirgin özelliği, bu ihlalin bulunması hâlinde sözleşmeyi ortadan kaldırma hakkının doğrudan ortaya çıkması olduğu için, ek süre verilmesiyle bazı yükümlülükler açısından ihlâlin varlığı, esaslı ihlâle yaklaştırmaktadır. Karşııt görüş için bkz. Zeytin, s. 247.

27 Ek süre müessesesinin ihlâlin esaslı olup olmadığı konusundaki belirsizliği kaldırdığına ilişkin bkz. Flechtner, s. 71; Sevon, s. 228; Schwenzer/Schlechtriem, s. 1035; Viscasillas, 
kullanılabilmektedir. Bu kapsamda öncelikle ek süre kavramı ve ardından hangi durumlarda ek süre tayininin sözleşmeyi ortadan kaldırma hakkını sağlayacağı ifade edilecektir.

\section{a. Ek Süre Kavramı}

Satıcı, alıcıya yükümlülüklerini ifa etmesi için CISG m. 63'e dayanarak makul uzunlukta bir ek süre ${ }^{28}$ tanıyabilir ${ }^{29}$. CISG m. 63, belli yükümlülükler açısından sınırlandırılmış değildir; satıcı alıcının her türlü yükümlülügüne yönelik ek süre tayin edebiliri ${ }^{30}$. Ayrıca bu hüküm satıcıya, alıcıya ek süre tanımasında bir yükümlülük getirmemekte; satıcının takdirine bırakılmış bir hukuki imkân sağlamaktadır ${ }^{31}$.

Ek süre verilmesine ilişkin bildirimde bulunulması, CISG m. 11'de yer alan genel kural uyarınca herhangi bir şeklî şarta tâbi değildir ${ }^{32}$. Ek sürenin alıcıya bildiriminin hangi andan itibaren hüküm ve sonuç doğuracağ1, tartışmalı olmakla birlikte, kanaatimizce de satıcının bildirimde bulunma anından itibaren bu irade açıklamasının hüküm ve sonuçları doğmaktadır ${ }^{33}$.

Pilar Perales (2005) 'The Nachfrist Remedy' Celebrating Success: 25 Years United Nations Convention on Contracts for the International Sale of Goods, Singapore, s. 91.

28 Ek süre müessesesi, Alman Hukukunda "nachfrist"; Fransız Hukukunda ise "mise en demeure" olarak adlandırılmaktadır. Secreteriat Commentary (1978) Commentary on the Draft Convention on Contracts for the International Sale of Goods, UN DOC. A/CONF. 97/5, s. 49; Dayığlu, s. 46; Duncan, s. 1381.

29 Belirtmek gerekir ki, CISG m. 61/III hükmü uyarınca alıcının yükümlülüklerini yerine getirmesi amacıyla satıcının iradesi dışında, alıcıya mahkeme ya da hakem tarafından ek süre verilemez. Secretariat Commentary, s. 48; Zeytin, s. 247. Böylelikle uluslararası ticaret, Antlaşma'nın ruhuna uygun şekilde yerel ticaretin aksine hakem ve mahkemelerin öngörülemez sonuçlarına tâbi kılınmamıştır. Schwenzer/Schlechtriem, s. 1024. Bu hüküm aynı zamanda, satıcının sözleşmenin ihlâli için alıcıya başvurmaması durumunda, alıcının mahkemeden ek süre verilmesi yönündeki talebinin de reddedilmesi gerektiği anlamına da gelmektedir. Zirâ bu talebin kabulü, CISG m. 7/II uyarınca Antlaşma'nın genel ilkelerine aykırı olacaktır. Knapp, s. 449.

Schwenzer/Schlechtriem, s. 1035.

32 Viscasillas, s. 96; Zeytin, s. 252. Ancak bildirimin içeriğinin açık olması gerekir. Örneğin satıcının alıcıyı bir akreditif hesabı açmaya sürekli yönlendirmiş olması, ona ek süre tanıdığı anlamına gelmemektedir. Buna ilişkin olarak bkz. CIETAC, 28 Şubat 2005, CISGOnline 1580.

33 Zeytin, s. 252. Bu görüşe göre CISG m. 27'den yola çıkılmak suretiyle, uygun araçlarla yapılan bildirimin gecikmesinin riskine, alıcı katlanmalıdır. Kanışlı (2013), s. 51; Viscasillas, s. 96. 
Satıc1, kural olarak ek süre verilmesine ilişkin bildirimi borcun vadesinden önce gerçekleştiremez ${ }^{34}$. Ancak satıcının, alacağının muaccel olması için alıcıya yönelttiği irade beyanıyla ek süre tahsisine ilişkin irade beyanı birleştirilebilir. Bir davaya konu olayda, araç satışı konusunda anlaşan taraflar, semen ödeme borcunun satıcının alıcıya yapacağı bildirimle muaccel olacağını kararlaştırmıştır. Mahkeme, alacağın muaccel olmasına ve alıcıya ek süre tanınmasına ilişkin olarak iki ayrı bildirimde bulunması gerektiğine yönelik yorumun çok şekilci olacağına hükmetmiştir ${ }^{35}$. Her ne kadar kararda, vadeden önce ek süre tanınmasına yönelik bildirimin geçerliliğine ilişkin bir değerlendirme yapılmamış olsa da; iki ayrı bildirim yapılması gerektiğinin şekilci bir yaklaşım olduğu konusundaki tespiti, ek süreye ilişkin bildirimin, muacceliyet bildirimiyle birlikte vadeden önce yapılabileceğini desteklemektedir ${ }^{36}$.

Satıcı tarafından tayin edilecek ek sürenin belirsiz olmaması, yani belirli bir süreyi ihtiva etmesi ${ }^{37}$ ve CISG m. 63'e göre makul uzunlukta olması gerekir. Sürenin makul uzunlukta olması, somut olayın şartlarına uygun olarak $^{38}$ alıcıya yükümlülüklerini yerine getirmesi için yeterli sürenin tanınmış olmasın $1^{39}$ ifade eder. Örneğin bir hakem heyetinin kararına konu olayda semen ödeme borcunun ifası için yirmi günlük süre makul görülürken; başka bir olayda dört aylık süre makul süre olarak değerlendirilmiştir ${ }^{40}$. Makul sürenin belirlenmesinde malın fiyatındaki düşüşler, malın depolama masrafları, yükümlülüklerin ifası için alıcıya sözleşmede

$34 \quad$ Knapp, s. 459.

35 OLG München, 19 Ekim 2006, CISG-online 1394.

36 Schwenzer/Schlechtriem, s. 1037.

37 Nisan ayının 30'una kadar ya da 15 gün sonra gibi ifadeler belirli süreyi ihtiva eden bildirimlerdir. Buna karşılık "imkan bulur bulmaz" gibi muğlak ifadeler belirli süre ifade etmez.

38 Viscasillas, s. 99-100. Somut olayın şartları değerlendirilirken tarafların anlaşması, alışkanlıkları ve ticari teamüller göz önünde bulundurulur. Zeytin, s. 253.

39 Duncan, s. 1384; Sevon, s. 226; Schwenzer/Schlechtriem, s. 1038. TGI Strasbourg, 22 Aralık 2006, CISG-Online 1629 (Katot ışııı tüpü davası): bütün malları yüklemenin imkânsız olduğu bir durumda 7 günlük sürenin makul bir süreden kısa olduğuna hükmedilmiştir.

40 Int Ct Ukrainian CCI, 19 Eylül 2005, CISG-Online 1287; Ödeme için 20 günün makul olduğuna hükmedilmiştir. Serbian Chamber of Commerce, 15 Temmuz 2008, CISGOnline 1795: Dört aylık süre makul görülmüştür. 
tanınan ilk süre, ifa edememenin sebebi ve tebliğ zamanı gibi hususlar da dikkate alınmaktadır ${ }^{41}$. Öte yandan örneğin semenin ödenmesi için verilen ek sürenin, malın teslim alınması için tayin edilen ek süreden kısa olması tabiidir. Zirâ semenin ödenmesi için, malın teslim alınmasında olduğu kadar hazırlığın yapılması gerekmemektedir ${ }^{42}$.

Satıcının makul olmayan uzunlukta ek süre belirlemesi durumunda, alıcının başvurabileceği bir imkânının olup olmadığı tartışmalı olmakla birlikte; kanaatimizce de bu durumda alıcı, re'sen makul olarak varsayılmış süreyi dikkate alabilir ${ }^{43}$.

b. Ek Sürenin Hüküm ve Sonuçları

\section{i. Alıcının Ek Süre Boyunca Korunması ve Korumanın Sınırları}

Satıcının, alıcıya yükümlülüklerini yerine getirmesi amacıyla ek süre vermesiyle, alıcı bu süre boyunca satıcının bazı hukukî silahlarından korunur. CISG m. 63/II'ye göre satıcı, kural olarak ek süre içerisinde ne aynen ifayı talep edebilir, ne de sözleşmeyi ortadan kaldırma hakkını kullanabilir ${ }^{44}$. Ancak alıcının ek süre içinde yükümlülüklerini ifa etmeyeceğini açılaması durumunda satıc1, ek sürenin bitmesini beklemeden söz konusu haklarını kullanabilecektir.

Ek süre verilmesi, sözleşmedeki vadeyi uzatmamakta; yani sözleşmenin alıcı tarafından ihlâl edilmiş olduğu gerçeğini değiştirmemektedir ${ }^{45}$. Dolayısıyla ek süre içerisinde gecikmeden kaynaklı tazminat talebinde bulunulabileceği gibi, semenin ödenmemesinden kaynaklı faiz de talep edilebilir ${ }^{46}$. Ayrıca sözleşmede kararlaştırılmış cezai şart da ek süre devam ederken istenebilir. Satıcı, bu süre içinde CISG m. 88/II hükmü uyarınca

\footnotetext{
Zeytin, s. 253.

Zeytin, s. 253.

Kanışlı (2013), s. 52; Schwenzer/Schlechtriem, s. 1039.

44 Duncan, s. 1385; Sevon, s. 227; Kanışlı (2016), s. 476; Secretariat Commentary, s. 50; Schwenzer/Schlechtriem, s. 1040; Zeytin, s. 253; Viscasillas, s. 101. ICC Ct Arb, 1 Ocak 1992, 7585/1992, CISG-Online 105: ICC’nin önüne gelen bir olayda alıcıya üç ay ek süre tanındığı, bu üç aylık ek süre içerisinde alıcının ifa edemeyecek derecede finansal eksikliği olmasına rağmen satıcı ek süre boyunca sözleşmeyi ortadan kaldırmamıştır.
}

45 Knapp, s. 460; Sert, s. 233; Zeytin, s. 254.

46 Schwenzer/Schlechtriem, s. 1040-1041. Zeytin, s. 253 Kanışlı (2016), s. 477. Satıc1, tazminat hakkını alıcıya ek süre tanımayla yitirmediği gibi, tanınan ek sürede alıcının yükümlülügünü gereği gibi yerine getirmesiyle de kaybetmeyecektir. Zeytin s. 255. 
çabuk bozulabilen malları satabilir. Buna karşılık ek süre içerisinde CISG m. 65 uyarınca satıcının malların niteliğini belirleme hakkını kullanması ve CISG m. 88/I uyarınca malları satması mümkün değildir ${ }^{47}$.

ii. Ek Sürenin Sonuçsuz Kalması

Alıcıya yükümlülüklerini yerine getirmesi amacıyla tanınan ek sürenin sonuçsuz kalması durumunda, kendiliğinden bir sonuç doğmamakta; sonucun doğması için satıcının irade beyanında bulunması gerekmektedir. Satıcının, kullanacağı seçimlik hakkını ayrı bir irade beyanıyla ve kural olarak ek sürenin sonunda bildirmesi gerekir ${ }^{48}$. Ancak satıcının ek süre içinde, bu sürenin sonuçsuz kalması durumunda kullanacağı seçimlik hakkını bildirmesi de mümkündür.

Esaslı ihlâlin bulunması durumunda satıcı, ek süre verilmesinden bağımsız olarak ihlâlin gerçekleşmesinden itibaren sözleşmeyi ortadan kaldırma hakkına zaten sahiptir. Esaslı olmayan ihlâllerin, ek süre tayin edilmek suretiyle, "bir anlamda", esaslı ihlâle dönüştürülmesinde ise ikili bir ayrım yapılmalıdır. CISG m. 64/I-b hükmüne göre satıcının tanıdığı ek süre içerisinde asli yükümlülükler -yani semen ödeme borcu veya malı teslim alma borcu- alıcı tarafından yerine getirilmez veya yükümlülüklerin bu süre içerisinde yerine getirilmeyeceği açıklanırsa, satıcı, ihlâl esaslı olmasa dâhi sözleşmeyi ortadan kaldırabilir. Buna karşılık diğer yükümlülüklerin esaslı olmayan ihlâli halinde ek süre tanımanın, satıcıya sözleşmeyi ortadan kaldırma hakkı tanıyıp tanımayacağı ise tartışmalıdır ${ }^{49}$. Doktrinde hâkim olan, bizim de katıldığımız görüşe göre, diğer yükümlülükler, ancak asli yükümlülüklerin tam ve doğru şekilde ifa edilmesine hizmet etmeleri durumunda CISG m. 64/I-b kapsamında değerlendirilebilir ${ }^{50}$. Diğer bir deyişle, asli yükümlülüklerin ifa edilmesine hizmet etmeyen diğer yükümlülüklerin yerine getirilmesi amacıyla ek sürenin tayin edilmesi ve sonuçsuz kalması, satıcıya sözleşmeyi ortadan kaldırma hakkı sağlamaz. Bu durumda satıcı aynen ifayı talep etmek zorunda olup buna ek olarak tazminat talebi gibi diğer imkânlardan da faydalanabilir.

47 Madde 88/I uyarınca ikâme satışın yasaklanmasının sebebi, alıcının teslim alma için hazırlıklara başlamış olma ihtimalinin olması ve alıcının teslim almadaki ya da semen ödemedeki makul olmayan gecikmesinin burada mümkün olmamasıdır. Schwenzer/Schlechtriem, s. 1040.

48 Kanışlı (2016), s. 488.

49 Zeytin'e göre esaslı olmayan diğer bir yükümlülüğün ihlâli, ek süre tanınarak esaslı hale getirilemez. Zeytin, s. 257.

50 Knapp, s. 470; Kanışlı (2016), s. 488; Viscasillas, s. 96. 


\section{B. İHLÂLİN ŞARTLARI}

\section{Yükümlülüğün İhlâli}

Sözleşmenin ihlâli, her şeyden önce alıcının yükümlülüklerinden birini ihlâl etmiş olması şartına bağlıdır. CISG m. 61/I’e göre alıcının sözleşmeden ya da Antlaşma'dan doğan yükümlülüklerinden birini yerine getirmemesi durumunda ihlâlden bahsedilir. İhlâl edilen yükümlülügün asli yahut diğer yükümlülüklerden biri olmasının önemi bulunmamaktadır ${ }^{51}$. Külfetler, teknik anlamda bir yükümlülük olmadığı için külfete aykırı davranış, yükümlülüğün ihlâli anlamına gelmez ${ }^{52}$. İhlâlin esaslı olup olmaması ise, yukarıda ifade edildiği üzere yalnızca ihlâlin derecesiyle ilgili olup sözleşmenin ihlâl edilmiş olduğu sonucunu değiştirmemekte; buna karşılık satıcının sahip olduğu hakların kapsamını belirlemektedir.

\section{Alıcının Sorumluluktan Kurtulmamış Olması}

Alıcının, sözleşmenin ihlâlinden kaynaklanan sorumluluğu kusurdan bağımsız, objektif bir sorumluluk türüdür ${ }^{53}$. Kural olarak alıcının yükümlülüklerini ihlâlinde herhangi bir kusuru olmasa dâhi satıcı, ihlalden kaynaklanan tüm haklarını kullanabilir. Ancak, istisnaen alıcının CISG m. 79 ve 80 uyarınca veya sorumsuzluk anlaşması yapmak suretiyle sorumluluktan kısmen ve tamamen kurtulabilmesi mümkündür. Dolayısıyla sözleşmenin ihlâlinin gündeme gelebilmesi için kümülatif ikinci şart, alıcının ilgili maddeler veya sorumsuzluk anlaşması uyarınca sorumluluktan kurtulmamış olmasıdır.

Alıcının CISG m. 79'a göre yükümlülüklerini ifa etmemesinden dolayı sorumlu olmadığını ispat etmesi hâlinde, ifa etmemeden dolayı sorumluluğu kısmen ortadan kalkar. Bu durumda yalnızca CISG m. 79/V'e göre satıcının tazminat hakkı ortadan kalkmakta ${ }^{54}$; buna karşılık CISG m. 62 ila 65. mad-

51 Viyana Satım Antlaşması'na göre ihlal edilen borcun türü ve özellikleri önemli değildir. Erdem, s. 263; Schwenzer/Schlechtriem 1020; Sert, s. 229; Zeytin, s. 247.

52 Schwenzer/Schlechtriem, s. 1020. Zeytin, s. 247.

53 Knapp, s. 445; Sarkaya, s. 12; Schwenzer/Schlechtriem, s. 1020; Sert, s. 229; Zeytin, s. 247. Kusursuz sorumluluğun bulunması, "Common Law" hukuk sisteminin Antlaşma üzerindeki bir etkisini göstermektedir. Zirâ bu hukuk sisteminde sözleşmede üstlenilen her edim bir garanti edimi niteliğindedir. Bkz. Atamer, s. 229; Yılmaz, s. 99.

54 BGH, 27 Kasım 2007, CISG-online 1617: Yeniden satışın yapıldığı ülkedeki (Rusya) döviz dalgalanmaları alıcıya/yeniden satıcıya alım sözleşmesini iptal hakkı vermemektedir; zira CISG m. 79 hükmü satıcının/üreticinin semen talebine uygulanmaz. 
delerinde yer alan haklar geçerliliğini sürdürmektedir. CISG m. 80'deki durumun varlığı hâlinde ise alıcının sorumluluğu tamamen ortadan kalkar ${ }^{55}$. Yâni alıcının, yükümlülüklerinin ihlâlini satıcının kendi fiilinden veya ihmâlinden kaynaklandığını ispatlaması hâlinde, ne seçimlik haklar ne de tazminat hakkı gündeme gelir. Alıcının sorumluluğu, tarafların anlaşmasıyla da ortadan kaldırılmış olabilir. Taraflar, sözleşmeyle alıcının kasıtlı ihlâli ve hilesi dışındaki tüm durumlar açısından alıcı nezdinde sorumsuzluk hâli öngörebilirler ${ }^{56}$.

\section{ALICININ YÜKÜMLÜLÜKLERINI İHLÂL ETMESİ DURUMUNDA SATICININ HAKLARI}

CISG m. 61/I uyarınca alıcının sözleşmeden ya da Antlaşma'dan kaynaklanan yükümlülüklerinden birini ihlâl etmesi hâlinde satıc1, 62 ilâ 65 . maddedeki ve 74 ilâ 77 . maddelerdeki haklarını kullanması mümkündür ${ }^{57}$. 62 ilâ 65. maddelerde yer alan haklar sözleşmenin alıcı tarafından ihlâline özgü şekilde düzenlenmişken; 74 ilâ 77. maddelerde ise alıcı ve satıcı açısından ortak olarak öngörülmüş tazminat talebinde bulunma hakkı yer almaktadır. Bu kapsamda satıcının seçimlik olarak aynen ifayı talep etme ve sözleşmeyi ortadan kaldırma hakkı bulunmakta; satıcı bunlara ek olarak tazminat talebinde de bulunabilmektedir.

Öte yandan satıcının, Antlaşma'nın 'satıcının ve alıcının yükümlülüklerine ilişkin ortak hükümler' başlıklı beşinci bölümünde (m. 71 ilâ 88 ) yer alan haklardan da faydalanması mümkündür. Dolayısıyla CISG m. 61/I'de

55 Satıcının sözleşmeden ve Antlaşma'dan kaynaklanan yükümlülüklerini ifa etmemesi hâlinde, alıcıya karşı 62 ilâ 65 . maddelerde öngörülen haklarını kullanıp kullanamayacağ konusunda Antlaşma'da herhangi bir düzenleme yapılmamıştır. Buradaki problem, CISG m. 7/II uyarınca Antlaşma'nın temelinde yatan genel ilkelere veya bu tür ilkelerin mevcut olmaması hâlinde milletlerarası özel hukuk kuralları uyarınca uygulanması gereken hukuka göre çözümlenir. Knapp'e göre satıcı, yükümlülüklerini yerine getirmedikçe, sözleşmenin alıcı tarafından ihlâl edilmesine yönelik hukuki yollara başvuramaz. Knapp, s. 445. Kanaatimizce CISG m. 80 hükmü uyarınca, alıcının yükümlülüklerinin yerine getirilmemesine satıcının sebebiyet vermesi hâlinde de benzer bir durum geçerlidir.

56 Schwenzer/Schlechtriem, s. 1024'ten naklen "Staudinger/Magnus, Md. 61, para. 40-1".

57 Bortolotti, Fabio (2006) 'Remedies Available to the Seller and Seller's Right to Require Specific Performance (Articles 61, 62 and 28)' Journal of Law and Commerce, Cilt: 25, Sayı: 1, s. 335; Sevon, s. 222. Satıcının seçimlik hakları, alıcının seçimlik haklarıyla paraleldir. Knapp, s. 443; Secretariat Commentary, s. 48; Schwenzer/Schlechtriem, s. 1020. Zeytin, s. 246. 
belirtilmemiş olsa da satıcı; ifayı askıya alma (m. 71), alıcının ifa tarihinden önce sözleşmeyi esaslı şekilde ihlâl edeceğinin aşikar olması halinde sözleşmeyi ortadan kaldırma (m. 72), art arda teslimli sözleşmelerde sözleşmeyi ortadan kaldırma (m. 73), semen ödeme borcunun geciktirilmesi sebebiyle faiz talep etme (m. 78), malları üçüncü kişiye tevdi etme (m. 87) ve malları satma (m. 88) haklarına da sahiptir.

\section{A. AYNEN IFAYI TALEP ETME HAKKI}

Aynen ifayı talep etme hakkı, ihlâl edilen yükümlülüğün sözleşmede kararlaştırılan ya da Antlaşma'da öngörülen ifa modalitelerine uygun şekilde yerine getirilmesi talebini ifade eder ${ }^{58}$. Satıcı, alıcının yükümlülüklerinden birini ihlâl etmesi durumunda, söz konusu yükümlülüklerin aynen ifasını talep edebilir ${ }^{59}$ (CISG m. 62). Aynen ifa talebinin sınırları, diğer haklarda olduğu gibi dürüstlük kuralı çerçevesinde CISG m. 7/I hükmüyle çizilmiştir ${ }^{60}$.

Alıcının kusurundan ve ihlâlin esaslı olup olmadığından bağımsız olarak ortaya çıkan aynen ifa talebi, irade beyanıyla ya da dava yoluyla kullanılabilmektedir ${ }^{61}$. Aynen ifa talebi, yapma edimleri açısından hem geçmişteki

58 Işıntan, Pelin (2013) 'Uluslararası Satım Sözleşmelerine İlişkin Birleşmiş Milletler Antlaşması ve Borçlar Kanunu Düzenlemelerinde Aynen İfa Kavramı’ Galatasaray Üniversitesi Hukuk Fakültesi Dergisi, Sayı: 1, s. 163; Sert, s. 54. Sözleşmenin ihlâl edilmesi durumunda aynen ifa talebi, Kara Avrupası hukukunda daha sıkı bir şekilde uygulanırken Anglosakson hukukunda ancak bazı şartlar altında uygulanabilmektedir (Işıntan, s. 166, Schwenzer/Schlechtriem, s. 1027). ULIS’te güçlü şekilde savunulan Anglosakson sisteminden, Viyana Satım Antlaşması’yla vazgeçilmiş, Kara Avrupası hukuk sistemine yaklaşılmıştır (Schwenzer/Schlechtriem, s. 1027).

59 Satıcı, aynen ifa talebini CISG m. 11 uyarınca herhangi bir şekli şarta bağlı kalmaksızın ileri sürebilir. Knapp, s. 453. Madde 62, satıcıya bütün akdi edimlerin aynen ifa talebinde bulunması imkânını sağlamaktadır. Schwenzer/Schlechtriem, s. 1029. CISG m. 62'de satıcı için öngörülmüş aynen ifa talebi, alıcı açısından CISG m. 46'nın paralel bir görünüm biçiminden ibarettir, Erdem, s. 267; Sert, s. 231.

İspat yükü konusunda Antlaşma'da doğrudan bir hüküm olmasa da, sistematik aracılığıyla ispat yüküne ilişkin çeşitli sonuçlara ulaşmak mümkündür. Buna göre satıcının, alıcının yükümlülüklerini yerine getirmekle yükümlü olduğunu ve bu yükümlülügü ihlâl ettiğini ispat etmekle yükümlüdür.

60 Başoğlu, Başak; 'Milletlerarası Mal Satımına İlişkin Sözleşmeler Hakkında Birleşmiş Milletler Antlaşması Uyarınca Aynen İfa ve Bunun Tarihsel Arka Planı' : Okur, Sinan (Editör) (2016) Milletlerarası Mal Satım Hukuku, Ankara, Adalet, s. 348; Schwenzer/Schlechtriem, s. 1029.

61 Zeytin, s. 249. 
hem de gelecekteki edimleri kapsarken; yapmama edimleri açısından işin tabiatına uygun olarak yalnızca gelecekteki edimler bakımından söz konusu olmaktadir ${ }^{62}$.

Alıcının yükümlülüklerine münhasır edimler açısından aynen ifa talebinin sınırlarını incelemeden önce, talebin genel olarak sınırlarını ifade etmek gerekir. İlk olarak aynen ifa talebi, CISG m. 28 uyarınca yalnızca, aynen ifa müessesesinin olduğu hukuk sistemlerinde kabul görür. Diğer bir deyişle aynen ifa talebinde bulunulan mahkemenin bağlı olduğu milli hukuk sisteminde aynen ifa müessesi yoksa, mahkeme aynen ifaya hükmetmek zorunda değildir ${ }^{63}$. Buna karşılık, aynen ifa talebinin irade beyanıyla kullanıldığı durumlarda, alıcı bu talebi kabul ederse kanaatimizce mahkeme kanalına başvurulmadığından CISG m. 28 hükmünün uygulanması gündeme gelmeyecektir.

İkinci olarak CISG m. 62'ye göre aynen ifa ile bağdaşmayan taleplerde bulunulması durumunda, aynen ifa talep edilemez. Örneğin sözleşmenin ortadan kaldırılması hakkının kullanılması durumunda, artık aynen ifa talebinde bulunmak mümkün olmayacaktır ${ }^{64}$. Aynen ifa talebiyle bağdaşmayan bir diğer hukuki imkân da ifa menfaatinin talebini ihtiva eden tazminat davasının açılmış olmasıdır ${ }^{65}$. Ayrıca CISG m. 63/II uyarınca alıcının yükümlülüklerini yerine getirmesi amacıyla kendisine tanınan ek süre içerisinde de aynen ifa talebine başvurulamaz. Zirâ satıcı bir yandan alıcının yükümlülüklerini yerine getirmesi amacıyla ona ek süre tanırken; diğer yandan aynen

62 Yapmama edimleri açısından aynen ifa talebinin önleyici işlevi ön plana çıkmaktadır. Kanışli (2016), s. 478.

63 Atamer, s. 263; Başoğlu, s. 358; Bartolotti, s. 337; Erdem, s. 265; Kanışlı (2016), s. 478; Secretariat Commentary, s. 48; Zeytin, s. 249. Bu hükümle birlikte Viyana Satım Antlaşması, Anglosakson hukuk sistemine tâbi mahkemelere, Kara Avrupası hukuk sisteminin aynen ifaya zorlayan sistematiğinden kurtulma imkânı sağlamıştır. Schwenzer/Schlechtriem, s. 1031.

CISG m. 28 hükmü, şimdiye kadar yalnızca bir karara konu olmuştur. Başoğlu, s. 358. Alman satıcı ile Amerikalı alıcı 4000 ton çelik alımı üzerine anlaşırlar. Satıcı, akreditifte bir değişiklik yapılmasını talep eder, ancak akreditif işlemi yapılamaz. Satıcı, bunun üzerine aynen ifayı talep eder. Mahkeme, kararında CISG m. 28 hükmüne yer vererek Amerikan Yeknesak Ticaret Kanunu uyarınca mevcut şartlarda aynen ifa talebinde bulunulamayacağını hükme bağlar. Bkz. US District Court for the Northern District of Illinois; 7 Aralık 1999, CLOUT Case 417.

64 Başoğlu, s. 352; Knapp, s. 448; Secretariat Commentary, s. 49; Zeytin, s. 251.

65 Schwenzer/Schlechtriem, s. 1030. Ancak bütünlük menfaatine ilişkin tazminat talebi, ifa ile bağdaşmayan bir talep olarak değerlendirilmeyecektir. Başoğlu, s. 352. 
ifayı derhal talep edebilmesi mümkün olmamalıdır ${ }^{66}$. Öte yandan satıcının, kademeli olarak önce aynen ifa talebinde bulunup bundan bir sonuç alınamaması hâlinde sözleşmeyi ortadan kaldırma hakkını kullanması mümkündür ${ }^{67}$.

Son olarak satıcı, alıcının sorumluluğunun CISG m. 80 uyarınca ortadan kalktığı ölçüde aynen ifa talebine başvurması mümkün değildir. Örneğin tarafların yaptığı sözleşmede, alıcıya akreditif düzenleme yükümlülüğü getirilmiş; ancak bu yükümlülügün ifası için satıcının alıcıya akreditif taslağı sunması öngörülmüşse; satıcının bu taslağı alıcıya sunmaması hâlinde alıcı akreditif düzenleme yükümlülüğünden CISG m. 80 uyarınca kurtulmuş olur $^{68}$. Dolayısıyla bu durumda artık satıcının, akreditif düzenleme yükümlülüğünün yerine getirilmesi amacıyla alıcıya aynen ifa talebi yöneltmesi mümkün değildir.

Aynen ifayı talep etme hakkına ilişkin genel açıklamalarımızın ardından; sırasıyla alıcının asli yükümlülükleri ve diğer yükümlülükleri bakımından aynen ifa talebinin incelenmesi gerekir.

\section{Semenin Ödenmesi Açısından Aynen İfayı Talep Etme Hakkı}

Alıcının semen ödeme borcu, CISG m. 58'e göre tarafların belirlediği vadede yahut böyle bir vade belirlenmemişse malın veya malları teslim eden belgelerin alıcının tasarrufuna hazır bulundurulduğu anda muaccel hâle gelir ${ }^{69}$. Muaccel hâle gelen semen ödeme borcunun ifa edilmemesi hâlinde satıc1, semen ödeme yükümlülüğü bakımından CISG m. 62'ye göre aynen ifa talebinde bulunabilir.

66 Knapp, s. 454; Schwenzer/Schlechtriem, s. 1029.

67 Zeytin, S. 251. Satıcı, alıcıya aynen ifa talebinde bulunduktan sonra; hâlen ifa gerçekleşmediyse mahkeme ya da hakem heyeti önünde sözleşmeyi ortadan kaldırma veya diğer yollara da başvurabilmelidir. Knapp, s. 455; Schwenzer/Schlechtriem, s. 1058.

68 Schwenzer/Schlechtriem, s. 1023.

${ }^{69}$ CISG m. 58; c. 1: "Alıcının semeni belirli başka bir anda ödeme yükümlülüğü yoksa, satıcının sözleşme veya bu Antlaşma uyarınca malları veya malları temsil eden belgeleri tasarrufuna hazır bulundurduğu anda ödemeyi yapması gerekir.” CISG m. 58'in uygulanmasına ilişkin CISG Danışma Kurulu görüşü için bkz. CISG-DK Görüşü; No. 11, Alıcının Ödeme Borcu Kapsamında CISG Uyarınca Belgelerden Doğan Sorunlar, 03 Ağustos 2012, <http://www.cisgac.com/file/repository/Turkish_No_11_SON.pdf> s.e.t. 03.04.2018. 
Satıcının aynen ifa talebiyle birlikte, CISG m. 78'e dayanarak faizin ve CISG m. 74'e dayanarak faiz ile karşılanamayan zararların (munzam zararlar) talep edilebilmesi mümkündür ${ }^{70}$. Faizin hesaplanmasında başlangıç anı, semen ödeme borcunun muaccel olduğu andır. Zarardan bağımsız olarak talep edilebilen faiz için satıcının alıcıya karşı bildirimde bulunmasına gerek yoktur; faiz her hâlükârda semen ödeme borcunun muaccel olmasından itibaren işler ${ }^{71}$. Hatta satıcı, alıcıya yükümlülüklerini yerine getirmesi için ek süre tanısa dâhi, ek süre içerisinde de faiz kendiliğinden işlemeye devam etmektedir ${ }^{72}$. Alıcının CISG m. 79 uyarınca sorumluluktan kurtulması, faiz ödeme borcuna etki etmemektedir ${ }^{73}$.

Faizle ilgili temel olarak iki hususta belirsizlik söz konusudur. İlk olarak faiz ödeme borcunun zamanaşımı neye göre belirlenmelidir? Bu konuda CISG'da bir düzenleme bulunmaması sebebiyle, kanunlar ihtilafı kuralları uyarınca yetkili ülkenin hukukuna göre hareket edilmelidir. İkinci olarak satıcının alıcıdan talep edeceği faiz, hangi oran üzerinden hesaplanacaktır? Zamanaşımı hususuyla benzer şekilde, isabetli bir şekilde bu konuda da CISG'da herhangi bir düzenleme yapılmamıştır. Oranın belirlenmesinde kanunlar ihtilafı kurallarına başvurmak gibi çeşitli görüşler ${ }^{74}$ ileri sürülse de CISG Danışma Kurulu'nun görüşü uyarınca kanaatimizce de faiz oranının

70 Vilus, Jelena (1986) 'Provisions common to the obligations of the seller and the buyer' International Sale of Goods: Dubrovnik Lectures, Occena, s. 252; Kanışlı (2016), s. 479; Secretariat Commentary, s. 48. Satıcı, sözleşmeyi ayakta tutar, semenin aynen ifasını talep ederse, ifa edilmemeden kaynaklanan zararlar değil; sadece ifanın gecikmesi sebebiyle ortaya çıkan zararlarını tazmin edebilir. OLG Karlsruhe, 8 Şubat 2006, CISG-Online 1328: malların geç teslim alınmasına bağlı olan muhafaza masrafları semene ek olarak tazmin edilebilir. Argentina Appellate Court, 21 Temmuz 2002, CLOUT Case 636: Alıcının malları teslim almış, malların sözleşmeye uygun olmaması nedeniyle semen ödemeyi reddetmiştir. Mahkeme, Arjantin hukuku uyarınca alıcının malın sözleşmeye uygun olmadığına yönelik yeterli delil sunmamasından hareketle CISG m. 62 uyarınca semenin aynen ifa edilmesine ve $m .78$ uyarınca faiz ödenmesine hükmetmiştir.

71 Kanışlı (2016), s. 480.

72 Kanışlı (2016), s. 480. Ek süre tanımanın faiz borcuna etki etmeyeceği yönündeki açıklamalarımız için bkz. "alıcının ek süre boyunca korunması ve korumanın sınırları" başlığı.

73 Magnus, Ulrich (2005) 'The Remedy of Avoidance of Contract Under CISG - General Remarks and Special Cases' Journal of Law and Commerce, Haziran, Say1: 25, s. 297.

74 Ayrıca alacaklının işyerindeki veya borçlunun işyerindeki faiz oranının ya da uluslararası faiz tablolarının uygulanabileceği de savunulmaktadır, bkz. Kanışı (2016), s. 481; Zeytin, s. 324 . 
belirlenmesinde en verimli seçim, faiz borcu açısından alacaklı sıfatını taşıyan satıcının işyerinin bulunduğu yer hukuku kurallarının uygulanmasıdır ${ }^{75}$. Böylelikle meseleye, kendisine ödeme yapılacak olan satıcı açısından öngörülebilir ve makul bir çözüm getirilmiş olur.

Semen ödeme borcunun aynen ifasına ilişkin CISG'da çeşitli sınırlamalar bulunmaktadır. CISG m. 77’ye göre satıcı, ihlâlden doğan zararı azaltmak için şartlara göre makul olan bütün tedbirleri almakla yükümlü kılınmış; tedbirlerin alınmaması hâlinde alıcıya alınacak önlemlerle zararın azaltılabileceği oranda tazminattan indirim yapılmasını talep etme hakkı tanınmıştır. Ancak satıcı, bazı durumlarda zararı azaltma külfeti kapsamında sözleşmeyi ortadan kaldırmak zorunda kalabilì ${ }^{76}$. Örneğin piyasa fiyatı ciddi şekilde düşen bir mal açısından, zararın azaltılması amacıyla sözleşmeyi ortadan kaldırmak, satıcı için bir zorunluluk arz etmektedir. Satıcının zararı azaltmak için sözleşmeyi ortadan kaldırmak zorunda olduğu hâllerde, aynen ifa talebine başvurulamayacaktır. Ayrıca CISG m. 71'e göre alıcının yükümlülüklerini askıya almasi ${ }^{77}$ ve CISG m. 50'ye göre malların sözleşmeye uygun olmaması durumunda ${ }^{78}$ da semen ödeme borcunun miktarı bakımından aynen ifa talebine sinırlamalar getirilmiştir.

\section{Malın Teslim Alınması Açısından Aynen İfayı Talep Etme}

\section{Hakkı}

Alıcının malı teslim alma borcu, yukarıda ifade edildiği üzere hazırlık fiillerinden ve malın fiilen teslim alınmasından oluşmaktadır. Satıcı, alıcının malı teslim alma yükümlülüğünü yerine getirmemesi hâlinde, kural olarak

75 CISG-DK Görüşü No. 9, Sözleşmeden Dönmenin Sonuçları, 15 Kasım 2008, $<$ http://www.cisgac.com/file/repository/Turkish_No_9_SON.pdf> s.e.t. 03.04.2018, m. 3.4: "Satım bedeline işleyecek faiz genellikle satıcının iş yerinin bulunduğu yerde olağan olan ticari faiz oranına göre belirlenir.”; CISG-DK Görüşü; No. 14, CISG Madde 78 Uyarınca Faiz, 21 Ekim 2013, <http://www.cisgac.com/file/repository/Turkish_No_14_SON.pdf> s.e.t. 03.04.2018, m. 9: “...uygulanacak faiz oranı, alacaklının işyerinin bulunduğu yerdeki mahkemenin, CISG’’n uygulama alanına girmeyen benzer bir satım sözleşmesine uygulayacağı orandır."

76 Kanışlı (2016), s. 479.

77 Zeytin, s. 250. CISG m. 71 uyarınca alıcı, şartların gerçekleşmesi hâlinde kendi yükümlülüklerinin ifasını askıya alabilir.

78 CISG m. 50'ye göre alıcı, malların sözleşmeye uygun olmaması durumunda semeni orantılı olarak indirme hakkına sahiptir. 
CISG m. 62 uyarınca aynen ifa talebinde bulunabilir ${ }^{79}$. Ancak satıcının malı teslim alma yükümlülüğünün aynen ifasında, semen ödeme borcunda olduğu kadar menfaati yoktur ${ }^{80}$. Zirâ alıcının, malı teslim alma yükümlülüğünün bir parçası olan hazırlık fiillerini gerçekleştirmemesi durumunda, satıcı CISG m. 65 uyarınca malın niteliklerini bizzat belirleyebilecektir ${ }^{81}$. Ayrıca malı fiilen teslim almayan alıcıya karşı satıcı, semenin ödenmesi hususunda aynen ifa talebinde bulunabileceğ ${ }^{82}$ gibi, malın CISG m. 87 uyarınca masrafı alıcıya ait olmak üzere üçüncü kişiye tevdi edilmesi ya da CISG m. 88 uyarınca koruma amaçlı olarak satılması yollarına da başvurabilir. Zaten malın teslim alınmaması hâlinde malın muhafazası (m. 85), üçüncü kişiye tevdi edilmesi (m. 87) ve satılması (m. 88) için makul önlemlerin alınması aynı zamanda satıcının yükümlülüklerindendir ${ }^{83}$. Bunlardan başka, alıcının malları teslim almamasının esaslı bir ihlâl teşkil etmesi hâlinde, satıcı sözleşmeyi ortadan kaldırabilir.

Malın teslim alınmasına yönelik aynen ifa talebiyle birlikte, malın teslim alınmaması sebebiyle ortaya çıkan zararların CISG m. 74 hükmü uyarınca talep edilmesi mümkündür. Örneğin satıcının işyerinde teslim edilmesi kararlaştııılan malların teslim alınmaması, satıcının fazladan depolama masrafı yapmasına sebep olmuşsa, satıcı bu masrafları alıcıdan talep edebilir.

Satıcının aynen ifa ve tazminat talebi için Antlaşma'da bir zaman sınırı belirtilmemiştir. Problemin kanunlar ihtilafı kurallarıyla belirlenen yetkili hukuk sistemine göre çözümlenmesi isabetlidir ${ }^{84}$.

79 Ayrıca ifade etmek gerekir ki, malı teslim alma borcu açısından temerrüde düşülme anından itibaren hasar CISG m. 69 uyarınca alıcıya geçmektedir.

80 Bartolotti, s. 338; Schwenzer/Schlechtriem, s. 1030. CISG'1n 1978 yllında yayımlanan taslağının, 62. maddesine karşıllı gelen 58. maddesinin Sekreterya tarafından yapılan şerhine göre, satıcının asli menfaati semenin ödenmesidir. Secretariat Commentary, s. 48.

81 Schwenzer/Schlechtriem, s. 1030.

82 Sevon, s. 233. Bu yola başvurması hâlinde, satıcının semenin ödenmesi üzerine, satış sözleşmesinden beklediği asıl menfaat de gerçekleşmiş olacaktır. Dolayısıyla malın teslim alınıp alınmaması, satıcı açısından ikincil önemi haizdir. Schwenzer/Schlechtriem, s. 1030.

83 Kanışlı (2016), s. 482.

84 Huber, Peter/Mullis, Alastair (2007) The CISG: A New Textbook for Students and Practitioners, München, European Law Publishers, s. 324. 
Aynen ifayı talep etme hakkının genel sınırları, malı teslim alma borcu açısından da geçerlidir; buna ek olarak malı teslim alma borcu bakımından malların CISG m. 88 uyarınca koruma amaçlı satılması hâlinde, aynen ifa talep edilemez. CISG m. 77 uyarınca zararı azaltma külfeti kapsamında sözleşmenin ortadan kaldırılması bir zorunluluk arz ediyorsa, bu durumda da artık aynen ifa talebinde bulunulamayacaktır.

\section{Diğer Yükümlülükler Açısından Aynen İfayı Talep Etme Hakkı}

Aynen ifa imkânını düzenleyen CISG m. 62'de, asli ve diğer yükümlülükler arasında herhangi bir ayrım yapılmamıştır. Bu çerçevede alıcının diğer yükümlülüklerinin de aynen ifası talep edilebilir. Özellikle asli edimlerin tam ve doğru bir biçimde ifasına hizmet eden diğer yükümlülükler açısından aynen ifa talebinin bulunması önemlidir ${ }^{85}$. Örneğin alıcının akreditif düzenleme, bilgi verme, banka teminat mektubu sağlama ve malın özelliklerini belirleme borçları açısından aynen ifa imkânına başvurulabilir. Benzer şekilde faiz ödeme borcunun da aynen yerine getirilmesi talep edilebilir.

\section{B. SÖZLEŞMEYİ ORTADAN KALDIRMA HAKKI}

\section{Kavram Problemi}

Viyana Satım Antlaşması'nın orijinal metninde, esaslı ihlâl durumunda sözleşmenin ortadan kaldırılma imkânı için "avoidance" terimi kullanılmış; bu terim Antlaşma’nın resmî Türkçe çevirisinde "sözleşmeyi ortadan kaldırma hakk»" olarak ifade edilmiştir. Türk doktrininde konuyla ilgilenen yazarlar ise, terminolojik incelemede bulunmaksızın istikrarlı bir şekilde söz konusu hak için "dönme" ${ }^{86}$ kavramını kullanmıştır. Müessesenin

85 Kanışlı (2016), 483.

86 Kee/Munoz'a göre Viyana Satım Antlaşması'ndaki “avoidance”, Alman Hukukunda birebir "rücktritt" kavramını karşılamaktadır. Buna karşılık "avoidance", İsviçre hukukundaki "rücktritt" kavramıyla örtüşmez. Kee, Christopher/Munoz, Edgardo (2009) 'In Defence of The CISG' Deakin Law Review, Cilt: 14, Sayı: 1, s. 122. Rücktritt kavramı BGB $\$ 325$ ve 326’da düzenlenmiştir. Chengwei, Almanca “Rücktritt” terimini, İngilizce “termination" kavramına karşılık olarak kullanmış ve bu müessesenin sonucunun, ifası gerçekleşmiş ve gerçekleşecek edimlerin iadesi yükümlülüğü doğurduğunu ifade etmiştir. Chengwei, Liu (2004) 'Comparison of CISG Article 45/61 remedial provisions and counterpart PECL Articles 8:101 and 8:102' Guide to Article 45, <http://cisgw3.law. pace.edu/cisg/text/peclcomp45.html $\geq$ s.e.t. 18.05.2018, s. 363-364. Schlechtriem, Viyana Satım Antlaşması'ndaki "avoidance" müessesinin BGB'de "rescission" (Rücktritt) olarak 
muhtevasını incelemeye geçmeden önce kavramın terminolojik olarak değerlendirilmesi elzemdir. Zirâ her alanında söz ve söze yüklenen anlam üzerinden hareket edilen bir alan olan hukukta kavramlar, kanaatimizce doğrudan müesseselerin içeriğine, şartlarına, sınırlarına ve sonuçlarına tesirde bulunmaktadır.

Antlaşma'nın resmî Türkçe çevirisinde, bilinçli olmayan bir şekilde kullanıldığını düşündüğümüz "sözleşmeyi ortadan kaldırma hakkı" teriminin, öncelikle Antlaşma'daki ifa engellerine yaklaşım tarzı doğrultusunda değerlendirilmesi gerekir. Yukarıda da ifade edildiği üzere Antlaşma, ifa engellerine Kara Avrupası hukuk sisteminden farklı bir tarzda, bütüncül bir bakış açısıyla yaklaşmış ve tüm ifa engellerini sözleşmenin ihlâli (breach of contract) kavramı çatısı altında toplamıştır. Buna bağlı olarak Antlaşma'nın ifa engellerinin sonuçlarının da daha sade bir yapıda olduğu söylenebilir. Sadelik, özellikle sözleşmenin sona erdirilmesi konusunda daha da ön plana çımaktadır. Sözleşme ilişkisinin sona erdirilmesi, Türk/İsviçre hukuk sisteminde sözleşmenin iptali, sözleşmenin feshi, sözleşmeden dönme, sözleşmeyi geri alma gibi her biri birbirinden farklı müesseseler ihtiva $\operatorname{eder}^{87}$. Buna karşlık Antlaşma'da ise sözleşmenin sona erdirilmesi için çatı müessese olarak "avoidance" öngörülmüştür. Kanaatimizce tek başına bu durum dâhi, "avoidance" kavramını "dönme"yle geçiştirmemek için yeterli bir sebeptir.

Kavram problemini ayrıca "avoidance" müessesine bağlanan sonuçlar yönünden de değerlendirmek gerekir. Antlaşma'daki “avoidance” kurumu, Türk/İsviçre hukukundaki dönmenin sınırlarından daha geniştir. Öyle ki taraflar, “avoidance”a sözleşmenin esaslı ihlâlinin yanı sıra Antlaşma’nın 72. maddesindeki ifa tarihinden önce sözleşmenin esaslı şekilde ihlâl edileceğinin aşikâr olması ve 73. maddesindeki art arda teslimli sözleşmeler açısından da başvurabilmektedir.

Netice itibariyle, Antlaşma'da düzenlenen ve sözleşmeyi ortadan kaldırma sonucu doğuran bu imkânı dönme olarak ifade etmenin isabetsiz

ifade edildiğini belirtmiştir. Schlectriem, Peter (2006) 'Subsequent Performance and Delivery Deadlines - Avoidance of CISG Sales Contracts Due to Non-conformity of the Goods' Pace International Law Review, Sayı: 1, s. 83. 
olduğunu düşünüyoruz. Antlaşma'nın ifa engellerine bütüncül bir bakış açısıyla yaklaşması ve "avoidance"ın sınırlarının Türk/İsviçre hukukundaki "dönme"nin sınırlarından daha geniş olması nedenleriyle bu müessesenin "sözleşmeyi ortadan kaldırma hakkı" olarak kullanılmasının daha isabetli olduğu kanaatindeyiz". Dolayısıyla çalışmamızda "sözleşmeyi ortadan kaldırma hakkı" ifadesi tercih edilecektir.

\section{Genel Olarak}

Sözleşmeyi ortadan kaldırma hakkı, sözleşmenin alıcı tarafından ihlâlinde satıcının başvurabileceği seçimlik haklardan birisidir ${ }^{89}$. Antlaşma'nın, taraflar arasındaki sözleşmeyi olabildiğince ayakta tutmaya yönelik yaklaşımı nedeniyle, bu hakka son çare (ultima ratio) olarak başvurulmalıdır ${ }^{90}$. Nitekim Antlaşma'da da kural olarak sözleşmeyi ortadan kaldırma hakkı yalnızca esaslı bir ihlâlin bulunması durumunda öngörülmüştür; diğer hallerde ise alıcı aynen ifa veya tazminat talep etme hakkını kullanılabilir"19.

Sözleşmeyi ortadan kaldırma hakkı, bozucu yenilik doğuran bir haktır; etkisi kullanmakla tükenir ve bu haktan kural olarak dönülemez ${ }^{92}$.

88 Ayrıca, Antlaşma'nın Türkçe’ye yapılan resmi çevirisinde 'sözleşmeyi ortadan kaldırma' ifadesinin bilinçli olarak kullanılmadığını düşünüyoruz.

89 Yâni sözleşmeyi ortadan kaldırma hakkına ilişkin şartların bulunması durumunda satıcı, bu hakkını kullanmak zorunda değildir. Dilerse diğer seçimlik haklarına da başvurabilir. Bu hak, satıcının sözleşmeyi ihlâli halinde alıcıya da tanınmış bir haktır; dolayısıyla hem satıcı hem de alıcının sözleşmeyi ortadan kaldırma hakkı bulunmaktadır. Sert, s. 233.

90 Erdem, s. 270; Kanışlı (2016), s. 484; Schwenzer/Schlechtriem, s. 1044-1045; Yılmaz, s. 100; Zeytin, s. 255. Sözleşmeyi ortadan kaldırma hakkının son çare olarak kabul edilmesinin; ahde vefa ilkesi, hakkın kullanılması neticesinde malın iadesinin büyük masraf ve risklere yol açacak olması, taraf menfaatlerinin değerlendirilmesi gibi çeşitli sebepleri vardır. Ayrıntılı bilgi için bkz. Yelkenci, s. 29 vd.; Yılmaz, s. 101.

91 Magnus, s. 424. Son çare ilkesine göre sözleşmenin ihlali hâlinde sözleşme ayakta tutulmaya çalışılacağı için esas talep, aynen ifa ve tazminat talebi şeklinde gerçekleşecektir. Kanışlı (2016), s. 485.

92 Knapp, s. 468; Zeytin, s. 258. Nadir de olsa sözleşmeyi ortadan kaldırma hakkını kullanmış olan satıc1, aynen ifa talebine dönmek isteyebilir. Alman doktrininde ittifakla satıcının artık böyle bir geçişe sahip olamayacağı kabul edilmiştir. Zira satıcının sözleşmeyi ortadan kaldırma hakkını kullanması yenilik doğuran hakkın (Gestaltungsrecht) uygulanması olarak görülür ve bunun sonucunda sözleşme artık tasfiye ilişkisine dönüşür. Schwenzer/Schlechtriem, s. 1059.

Bununla birlikte, dönme beyanı, sözleşmeyi ortadan kaldırmaya ilişkin beyandan önce veya bununla eş zamanlı olarak alıcıya ulaşırsa, sözleşmeyi ortadan kaldırma beyanının geçersiz sayılacağ kabul edilmelidir. Knapp, s. 468. 
Sözleşmeyi ortadan kaldırma hakkı, şartın tamamen alıcının eylemine bağlı olması durumu dışında, şarta bağlanamaz. Örneğin hakkın kullanımı, alıcıya tanınan ek sürede edimin ifa edilmemesi şartına bağlanabilirken ${ }^{93}$, satıcı tarafından tedarikçilerine cezai şart ödenmesi hâlinde kullanılacağ bağlanamaz.

Şartların varlığı hâlinde sözleşme kendiliğinden ortadan kalkmamakta; bunun için satıcının CISG m. 26 uyarınca ortadan kaldırma beyanında bulunması gerekmektedir ${ }^{94}$. Ek sürenin tanındığı hallerde de irade beyanında bulunulması şarttır. Sözleşmenin ortadan kaldırılmasına ilişkin irade beyanının hüküm ve sonuç doğurması için varması da gerekli değildir ${ }^{95}$; satıcının beyanda bulunduğu andan itibaren beyan, taraflar için hüküm ve sonuç doğurur.

Antlaşma'da sözleşmenin ortadan kaldırılmasına yönelik irade beyanı için herhangi bir şekli şart öngörülmemiştir; beyan sözlü, yazılı yahut başka bir yolla yapılabilirr' ${ }^{96}$ Diğer yandan bildirimin içeriğinin, kural olarak satıcının sözleşmeyi ortadan kaldırma hususundaki iradesini açıkça göstermesi gerekir. Ancak sözleşmenin ortadan kaldırılmasına ilişkin zımni bildirim de, somut olayın şartları çerçevesinde geçerli bir bildirim sayılabilmektedir. Örneğin dava açmak veya ifa menfaatini kapsayacak şekilde tazminat talep etmek, sözleşmenin ortadan kaldırılmasına ilişkin geçerli zımni bildirim kabul edilir ${ }^{97}$.

\section{3. Şartları}

Sözleşmeyi ortadan kaldırma hakkı, alıcının yükümlülüklerini esaslı şekilde ihlâl etmesi ya da alıcıya ek süre tanınmasına rağmen bu süre içerisinde ifanın gerçekleşmemesi durumlarında kullanılabilir. Bu iki hâl, hakkın kullanılması için kümülatif şart niteliğinde değildir; aksine bu iki durum, sözleşmenin ortadan kaldırılmasına ilişkin iki alternatif yolu ifade eder.

93 Schwenzer/Schlechtriem, s. 1057; Yelkenci, s. 143.

94 Erdem, s. 271; Kanışılı (2016), s. 485. Knapp, s. 468; Magnus, s. 426; Secretariat Commentary, s. 50; Yelkenci, s. 139; Zeytin, s. 258.

95 Schwenzer/Schlechtriem, s. 1056; Zeytin, s. 256-258. Farklı görüşler için bkz. Yelkenci, s. $145 \mathrm{vd}$.

96 Yelkenci, s. 142; Zeytin, s. 258.

97 Schwenzer/Schlechtriem, s. 1056. 
a. Esaslı İhlâlin Bulunması

CISG m. 25'e göre bir ihlâlin esaslı sayılabilmesi için ihlâl nedeniyle satıcının önemli menfaat kaybına uğraması ve bu kaybın sonuçlarının alıcı tarafından öngörülebilir olması gerekir. Sözleşmeyi ortadan kaldırma hakkı, kural olarak esaslı bir ihlâlin bulunması durumunda kullanılabilir. Esaslı ihlâlin varlığı hâlinde satıcı, alıcıya ek süre tanımaksızın doğrudan sözleşmeyi ortadan kaldırabilir.

Esaslı şekilde ihlâl edilen yükümlülügüun sözleşmeden ya da Antlaşma'dan kaynaklanmasının; asli veya diğer yükümlülüklerden olmasının bir önemi yoktur ${ }^{98}$. Dolayısıyla alıcının diğer yükümlülüklerinden birinin esaslı şekilde ihlâl edilmesi de, satıcıya sözleşmeyi ortadan kaldırma hakkı sağlar.

i. Semen Ödeme Yükümlülüğünün Esaslı İhlâli

Semen ödeme yükümlülüğünün ifasında temerrüde düşülmesi, ihlâli tek başına esaslı hâle getirmez. Esaslı ihlâl için semen ödeme yükümlülüğünün ifa edilmemesinin, satıcı nezdinde önemli bir menfaat kaybına neden olması ve bu sonucun alıcı tarafından öngörülebilir olması gerekmektedir.

Semen ödeme yükümlülüğünün, belirli bir vadeye bağlandığı durumlarda, zamanında ödeme yapılmaması esaslı bir ihlâl olarak kabul edilmemektedir ${ }^{99}$. Ancak kararlaştırılan vadenin satıcı için yüksek öneme sahip olması durumunda ("time is of essence") yükümlülügün ihlâli, önemli menfaat kaybına sebep olacak ve dolayısıyla esaslı ihlâl teşkil edecektir. Kararlaştırılan ödeme zamanının satıcı tarafından yüksek öneme sahip olup olmadığ 1 ise CISG m. 8 ve 9'a göre yorum faaliyetiyle tespit edilirr ${ }^{100}$. Örneğin aynı anda ifanın kararlaştırılması, kesin vadenin belirlenmesi (just in time), hızlı kur dalgalanmalarının olması, satıcının tedarikçilerine ödeme yap-

98 Zeytin, s. 256.

99 Sert, s. 234; Sarıkaya, s. 287; Kanışlı (2016), s. 489; Schwenzer/Schlechtriem, s. 1046. TGI Strasbourg, 22 Aralık 2006, CISG-Online 1629: Belirli bir vadenin kararlaştırıldığı sözleşmede, alıcının semen ödeme borcunu ifa etmede bir ay gecikmesi esaslı bir ihlâl teşkil etmez.

100 Sarıkaya, s. 285; Schwenzer/Schlechtriem, s. 1047. Kanışlı (2016), 489. 
maması durumunda cezai şart ödeyecek olması, sözleşmenin çabuk bozulabilen mallara ilişkin olması ve benzeri durumlarda ödeme zamanının satıcı bakımından yüksek önemi haiz olduğu ve dolayısıyla ihlâlin esaslı ihlâle sebebiyet vereceği mahkemelerce kabul edilmektedir ${ }^{101}$.

ii. Malı Teslim Alma Yükümlülügüüün Esaslı İhlâli

Semeni ödeme borcundaki durumla paralel şekilde, alıcının malı teslim alma borcunda temerrüde düşmesi, ihlâli tek başına esaslı hale getirmemektedir ${ }^{102}$. Ancak bu borcun muacceliyet anının satıcı açısından yüksek önem arz etmesi durumunda yükümlülüğün ihlâli, önemli menfaat kaybına neden olacağından, esaslı bir ihlâl teşkil eder ${ }^{103}$. Örneğin çabuk bozulabilen malların bulunması veya teslimin satıcının işyerinde kararlaştırıldığı durumlarda, ihlâl halinde satıcının depo masrafları yapacak olması ya da satıcının malları korumak için fahiş masraf yapacak olması durumlarında esaslı ihlâlden bahsedilir ${ }^{104}$. Benzer şekilde kesin vadenin kararlaştırıldığı hallerde de malın teslim alınmaması esaslı ihlâle sebebiyet verir.

iii. Diğer Yükümlülüklerin Esaslı İhlâli

İfade edildiği üzere, esaslı biçimde ihlâl edilen yükümlülüğün, asli veya diğer yükümlülüklerden birinin olmasının önemi yoktur. Esaslı olduğu sürece diğer yükümlülüklerin ihlâli de satıcıya sözleşmeyi ortadan kaldırma imkânı sağlar. Örneğin alıcının ödeme için akreditif açtırması kararlaştırılmış ve ödeme açısından tek yolun bu olduğu öngörülmüşse;

101 Kanışlı (2016), s. 489; Knapp, s. 469; Sarıkaya, s. 288; Benzer şekilde kural olarak alıcının iflası hâlinde de esaslı bir ihlâlden bahsedilir. Schwenzer/Schlechtriem, s. 1049. Örneğin, kararlaştırılan vadede akreditif açılmamasının ardından, talep edilen ek sürede de bedelin tamamen ödenmemesi ve malların geri kalanının teslim alınmaması esaslı ihlal oluşturabilecektir. Sarıkaya, s. 286. Çabuk bozulabilen malların satışı açısından alıcının semen ödeme borcunu zamanında getirmesinde yüksek menfaatinin bulunduğuna ilişkin bkz. OLG Düsseldorf, 22 Temmuz 2004, CISG-Online 919. Vadeden iki ay geçtikten sonra semenin \%20'sinden az bir kısmının ödenmesinin esaslı ihlâl teşkil edeceği hakkında bkz. USA New York Federal District Court, 29 Mayıs 2009 (Doolim Corp. v. R Doll, LLC, et al).

Sarıkaya, s. 291; Schwenzer/Schlechtriem, s. 1049; Viscasillas, s. 92.

Örneğin teslim almanın kesin vadeli olarak kararlaştırıldığı "just in time” sözleşmelerde malı teslim alma borcunun muacceliyet anı, satıcı açısından yüksek önem arz etmektedir. Sarıkaya, s. 291; Kanışlı (2016), s. 491; Zeytin, s. 257. 
akreditif açtırma yükümlülügünün ihlâli halinde sözleşmeyi ortadan kaldırma imkânı gündeme gelir ${ }^{105}$. Benzer şekilde alıcının sözleşmedeki yeniden ithal yasağına geniş ölçüde uymaması durumunda da esaslı bir ihlâlden söz edilirr ${ }^{106}$. Uygulamada alıcının diğer yükümlülüklerinden birini ihlal edip etmediğini ve bunun zamanını tespit etmek zor olduğundan, ancak alıcının satıcıya edimini ifa etmeyeceğini bildirdiği durumlarda esaslı bir ihlâlin varlığından şüphe edilmemektedir ${ }^{107}$.

b. Alıcıya Ek Süre Tanınmasına Rağmen Bu Süre İçinde İfa Etmeme Sözleşmenin esaslı bir şekilde ihlâl edilip edilmediğinin tespiti kolay değildir. Satıcı, alıcının yükümlülüğünü esaslı şekilde ihlâl ettiğini düşünerek sözleşmeyi ortadan kaldırdıktan sonra, mahkeme nezdinde ihlâlin esaslı olmadığına hükmedilebilir. Bu durumda alıcı tarafından esaslı bir ihlâl gerçekleştirilmeksizin satıcı sözleşmeyi ortadan kaldırma beyanında bulunmuş olacak; bu nedenle artık satıcının sözleşmeyi esaslı şekilde ihlâl etmesi gündeme gelecektir. Dolayısıyla satıcının sözleşmeyi ortadan kaldırması için en güvenli yol, alıcıya ek süre tanımaktır. Böylelikle satıcı, ihlâlin esaslı olduğuna yönelik ispat yükünden kurtularak sözleşmeyi tereddütsüz bir şekilde ortadan kaldırabilir. ${ }^{108}$

Ek süre vasıtasıyla sözleşmeyi ortadan kaldırma yoluna başvurabilmek için esaslı olmayan şekilde ihlâl edilen yükümlülügün ya asli ya da asli yükümlülüklerin tam ve doğru şekilde ifasına hizmet eden diğer yükümlülüklerden biri olması gerekir ${ }^{109}$. Tersinden ifade etmek gerekirse;

105 Kanışlı (2013), s. 77; Sarıkaya, s. 296.

106 Schwenzer/Schlechtriem, s.1050. CA, 22 Şubat 1995, CISG-Online 151: Fransız satıcıdan kot satın alan ABD'li alıcı, bunları aralarındaki sözleşmede yer alan yeniden ithal yasağına rağmen Avrupa'ya geri ihraç etmiştir.

107 Schwenzer/Schlechtriem, s. 1050.

108 Kanışlı (2016), s. 488; Knapp, s. 459; Schwenzer/Schlechtriem, s. 1051; Zeytin, s. 257. Ek süre tâyini, sözleşmenin ortadan kaldırılmasında alternatif güçlü bir araçtır. Duncan, s. 1381.

109 Diğer bir ifadeyle alıcının yan yükümlülüklerinin semen ödeme veya teslim alma borçlarının bir parçası olup olmaması büyük önem taşımaktadır. Örneğin akreditif hesabı açma gibi, alıcının semeni ödeme borcunun parçası olan yükümlülükler, CISG m. 64/Ib’nin uygulama alanındadır. Buna karşılık alıcının semen ödeme borcunun veya teslim alma borcunun bir parçasını oluşturmayan, alıcının malları belli ülkelere pazarlama ve dağıtma yükümlülüğü ise bu madde kapsamında satıcıya sözleşmeyi ortadan kaldırma hakkı vermeyecektir. Schwenzer/Schlechtriem, s. 1050-1051. Ayrıca bkz. Kanışl1 (2016), s. 491. Benzer şekilde satıcının, alıcının sözleşmede kararlaştırılan malların özelliklerini 
asli yükümlülüklerle ilişskisi kurulamayan diğer yükümlülüklerin ihlâlinde ek süre tanınsa dâhi bu sürenin sonunda, sözleşme ortadan kaldırılamaz. Yâni asli yükümlülüklerle ilişkisi olmayan diğer yükümlülüklerin, ancak esaslı şekilde ihlâl edilmesi hâlinde sözleşme ortadan kaldırılabilecektir.

Esaslı olmayan ihlâller bakımından ek süre verilerek sözleşmenin ortadan kaldırılabilmesi için öncelikle satıcının, alıcıya yükümlülügünü yerine getirmesi amaciyla CISG m. 63/I uyarınca makul uzunlukta bir ek süre tanıması gerekir. Ek süreye rağmen ifanın gerçekleşmemesi yahut bu süre içinde alıcının satıcıya ifayı gerçekleştirmeyeceğine yönelik bir bildirimde bulunması $^{110}$ durumunda, satıcı ihlâlin esaslı olup olmadığını dikkate almaksızın sözleşmeyi ortadan kaldırabilir. Örneğin satıcının, alıcının sözleşmede kararlaştırılan malların özelliklerini belirlememesi yükümlülüğünü yerine getirmemesi üzerine; ona ek süre tanıması ve ek sürenin sonuçsuz kalması halinde CISG m. 63/II hükmü uyarınca sözleşmeyi ortadan kaldırması mümkündür ${ }^{111}$.

Sözleşmenin esaslı şekilde ihlâl edilmesi durumunda, ek süre tayin etmeksizin sözleşmenin ortadan kaldırılması mümkündür. Ancak satıcı, esaslı ihlâl olsa dâhi alıcıya yükümlülüklerini yerine getirmesi amacıyla ek süre tanıyabilirr ${ }^{12}$. Bu durumda artık süre sonuçsuz kalana kadar veya süre içinde

belirlememesi yükümlülüğünü yerine getirmemesi üzerine ona ek süre tanıması ve ek sürenin sonuçsuz kalması halinde CISG m. 63/II hükmü uyarınca sözleşmeyi ortadan kaldırması mümkündür. Schwenzer/Schlechtriem, s. 1067.

110 Duncan, s. 1385. Söz konusu bildirim, alıcının red beyanı olup CISG m. 63/II uyarınca varması gerekli bir irade beyanıdır. Zeytin, s. 260. CISG m. 11'in geniş şekilde yorumlanması hâlinde bu bildirimin de herhangi bir şeklî şarta tabi olmaksızın yapılabileceği sonucuna ulaşılır. Knapp, s. 463. Alıcının ifayı gerçekleştirmeyeceğine yönelik beyanı açık olabileceği gibi, CISG m. 8'in yorumlanması suretiyle zımni de olabilir. Knapp, s. 463.

111 Schwenzer/Schlechtriem, s. 1067. Bu örnekte malın özelliklerini belirleme yükümlülügüu, asli yükümlülüklerin tam ve doğru bir şekilde ifasına hizmet eden diğer yükümlülüklerden birisidir.

112 Bu husus, satıcının CISG m. 64'e göre sözleşmeyi ortadan kaldırma hakkı veren bir ihlâlin bulunmasına rağmen alıcıya ek süre verebileceğini göstermektedir. Yâni satıcı, sözleşmeyi ortadan kaldırmak zorunda değildir. Başoğlu, s. 354; Duncan, s. 1383; Sarıkaya, s. 183; Kanışli (2016), s. 486.

Örneğin Seul Yüksek Mahkemesi'nin önüne gelen pamuk tohumu davasında satıcı, alıcıya esaslı bir ihlâl olmasına rağmen ek süre tanımıștır. Bkz. Republic of Korea, 14 Ekim 2010, Seoul High Court (Pamuk tohumu davası), CLOUT Case 1278. 
alıcının yükümlülüğü yerine getirmeyeceğine ilişkin satıcıya bildirimde bulunmasına kadar sözleşmeyi ortadan kaldırma hakkı kullanılamayacaktır.

\section{Sinırları}

Alıcının yükümlülüklerini yerine getirmemesi durumunda, şartları varsa satıcı dilediği zaman sözleşmeyi ortadan kaldırabilir. Viyana Satım Antlaşması'nda sözleşmeyi ortadan kaldırma hakkının sona ermesine ilişkin bir süre öngörülmemiştir. Bu konudaki tek sınır, kanunlar ihtilafı kuralları gereğince yetkili hukukun öngördüğü zamanaşımı süreleridir. ${ }^{113}$

Semenin ödenmiş olduğu bazı durumlarda ise, CISG m. 64/II uyarınca sözleşmeyi ortadan kaldırma hakkına zaman bakımından bazı sınırlamalar getirilmiştir ${ }^{114}$. Zirâ taraflar arasındaki sözleşme kapsamında satıcının en önemli menfaati semenin ödenmesidir; semenin ödenmesi durumunda satıcının menfaatleri büyük ölçüde karşılanır ${ }^{115}$. CISG m. 64/II’ye göre sözleşmeyi ortadan kaldırma hakkı; (a) gecikmiş bir ifanın bulunması ve (b) gecikmiş ifa dışındaki bir sözleşmeye aykırılığın bulunması hallerinde zaman bakımından sınırlandırılmıştır. Sınırlamaların geçerli olabilmesi için CISG m. 64/II’ye göre ön şart, semenin ödenmiş olmasıdır ${ }^{116}$. Zirâ semenin ödenmemiş olması hâlinde satıcı, zaten dilediği vakit sözleşmeyi ortadan kaldırabilir.

Öte yandan satıcının haklarına genel bir sınırlama getiren CISG m. 80 hükmünün, sözleşmeyi ortadan kaldırma hakkı açısından da geçerli olduğunu ifade etmek gerekir. Buna karşılık CISG m. 79'a göre alıcının sorumluluktan kurtulması, sözleşmeyi ortadan kaldırma hakkına etki etmeyecektir ${ }^{117}$. Zirâ 79 . maddede sorumluluktan kurtulma, yalnızca tazminat sorumluluğu bakımından geçerlidir.

113 Magnus, s. 428; Schwenzer/Schlechtriem, s. 1053. OLG München, 19 Ekim 2006, CISGonline 1394: Satıcının ifanın gerçekleştirilmesi için ek süre tayin edildikten sonra, altı ay beklemiş olması, sözleşmeyi ortadan kaldırma hakkından vazgeçtiği anlamına gelmez.

114 Knapp, s. 471; Zeytin, s. 259.

115 Schwenzer/Schlechtriem, s. 1055.

116 Jenkins, s. 411; Secretariat Commentary, s. 50. Semenin tamamının ödendiği durumlarda CISG m. 64/II uygulama alanı bulur; semenin kısmen ödenmiş olması bu hükmün uygulanması için yeterli değildir. Knapp, s. 471.

117 Zeytin, s. 256. 


\section{a. Geç İfa}

Satıc1, alıcının yükümlülüklerini geç de olsa ifa ettiği hallerde, kural olarak sözleşmenin ortadan kaldırılması hakkına başvuramaz. Ancak CISG m. 64/II-a'ya göre alıcının geç ifası hâlinde satıcı, eğer geç ifayı öğrenmeden önce sözleşmeyi ortadan kaldırma beyanında bulunursa, yapılan beyan geçerli bir biçimde hüküm ve sonuçlarını doğurur. CISG m. 64/II-a'nın uygulanabilmesi için geç ifanın esaslı bir ihlâl teşkil etmesi gerekir ${ }^{118}$. Zirâ esaslı olmayan ihlâller açısından sözleşmeyi ortadan kaldırma hakkı, ek süre tanınmadığı müddetçe gündeme gelmeyecektir.

Geç ifa, alıcının sonuçta edimini ifa ettiği; ancak ifada geç kaldığı bütün durumları kapsayan bir ifadedir ${ }^{119}$. Mefhum-u muhalifinden sözleşmeden ya da Antlaşma'dan kaynaklanan bir yükümlülüğün hiç ifa edilmemiş olması; geç ifa dışındaki ihlâli ifade etmekte ve bu da CISG m. 64/II-b’nin uygulanmasını gündeme getirmektedir. CISG m. 64/II-a'daki geç ifa durumunun semen ödeme borcunun dışında malı teslim alma ve diğer yükümlülüklere de uygulanması mümkündür ${ }^{120}$. Yâni örneğin malın vadesinden sonra teslim alınması durumunda, satıcı malın teslim alındığını öğrenmeden önce sözleşmeyi ortadan kaldırma hakkına başvurabilecektir ${ }^{121}$. Benzer durum, diğer yükümlülükler açısından da geçerlidir.

Geç ifaya ilişkin değinilmesi gereken bir diğer husus da, bunun gerçek anlamda bir sinırlama olup olmadığıdır. Kanaatimizce her ne kadar doktrinde sözleşmeyi ortadan kaldırma hakkının sınırları başlığında ifade edilse

118 Jenkins, Sarah H. (2013) 'Rejection, Revocation of Acceptance, and Avoidance: A Comparative Assessment of UCC and CISG Goods Oriented Remedies' Minnesota Journal of International Law, Cilt: 22, Sayı: 152, s. 412; Kanışlı (2016), s. 492; Knapp, s. 471.

119 Knapp, s. 471; Schwenzer/Schlechtriem, s. 1053.

120 Knapp, s. 472; Kanışlı (2016), s. 492; Schwenzer/Schlechtriem, s. 1053; Zeytin, s. 259. Bu husus Viyana Satım Antlaşması'nın hazırlık aşamasında da tartışma konusu olmuştur. Tartışma, nihayetinde iki farklı yorumun ortaya çımasına sebep olmuştur. İlkine göre geç ifa, semen ödeme dışındaki yükümlülüklerden bağımsız olarak ele alınmalıdır. Diğer bir yorum da, tüm yükümlülükler tamamlanana kadar satıcıya sözleşmeyi ortadan kaldırma hakkının tanınmalıdır. İki farklı yorum nedeniyle hükmün değiştirilmesi teklif edilmiş; ancak teklif reddedilmiştir. Knapp, s. 472'den naklen "Official Records, II, 412$413 "$.

121 İfade etmek gerekir ki, malı teslim alma borcunun yerine getirilmemesinin tıpkı semen ödeme borcunda olduğu gibi esaslı şekilde ihlâl edilmiş olması gerekir. 
de, geç ifa hâlinde aslında sözleşmeyi ortadan kaldırma hakkının kullanılmasına ilişkin zaman aralığı genişletilmektedir. Zirâ, satıcının geç ifa anına kadar sözleşmeyi ortadan kaldırması mümkün iken, bu hakkı kullanmaması hâlinde; geç ifanın ardından bu haktan yararlanamaması gerekirdi. Ancak CISG m. 64/II-a'da öngörülen hüküm nedeniyle satıcı, geç ifaya rağmen, geç ifayı öğrenmeden önce sözleşmeyi ortadan kaldırma hakkını kullanabilmektedir. Dolayısıyla burada bir sınırlama değil, esasında zaman bakımından bir genişletmenin söz konusu olduğu düşüncesindeyiz.

b. Gecikmiş İfa Dışındaki Bir Aykırılığın Bulunması

CISG m. 64/II-b hükmüyle, gecikmiş ifa dışındaki sözleşmeye aykırılık halleri için çeşitli sınırlamalar öngörülmüştür. Gecikmiş ifa dışındaki sözleşmeye aykırılıktan kast edilen, yukarıda ifade edildiği üzere, yükümlülüğün hiç ifa edilmemiş olmasıdır. CISG m. 64/II'nin uygulanabilmesi için ön şart semenin ödenmesi olduğu için, CISG m. 64/II-b'nin uygulanması en çok, semenin ödendiği, buna karşılık henüz malın teslim alınmadığı durumlarda gündeme gelmektedir ${ }^{122}$. Ancak teorik olarak semenin ödenip malın teslim alındığı; buna karşılık diğer yükümlülüklerin esaslı olarak ihlâl edildiği hallerde de CISG m. 64/II-b hükmü uygulanabilir.

Sınırlamalar, gecikmiş ifa dışındaki sözleşmeye aykırılık halleri için satıcının alıcıya bir ek süre tanıyıp tanımadığına göre ikiye ayrılmaktadır. Satıcının alıcıya ek süre vermediği hâllerde, alıcının gecikmiş ifa dışındaki sözleşmeye aykırıllğın satıcı tarafından bilindiği ya da bilinmesi gerektiği andan itibaren makul bir sürenin geçmesiyle birlikte satıcının sözleşmeyi ortadan kaldırma hakkı sona erer (m. 64/II-b-i). Bir diğer deyişle satıcının makul süre geçmeden sözleşmeyi ortadan kaldırma hakkını kullanması gerekmektedir.

Satıcının alıcıya yükümlülüklerini yerine getirmesi için ek süre tayin etmesi durumunda ise, CISG m. 63/II hükmü devreye girer ${ }^{123}$. Buna göre alıcıya tanınan ek sürenin geçmesinin ya da alıcının bu ek süre içinde yükümlülüklerini yerine getirmeyeceğini açıklamasının ardından makul bir sürenin geçmesi durumunda satıcı artık sözleşmeyi ortadan kaldıramaz (m.

\footnotetext{
122 Kanışlı (2016), s. 493.

123 Jenkins, s. 412; Secretariat Commentary, s. 50.
} 
64/II-b-ii). Diğer bir deyişle satıcının, sözleşmeyi ortadan kaldırma hakkını makul süre içinde kullanması gerekir; aksi hâlde CISG m. 64/II-b-ii gereğince satıcı, bu hakkını kaybedecektir.

CISG m. 64/II-b'de ifade edilen makul süreden ne anlaşılması gerektiği konusunda Antlaşma'da bir hüküm öngörülmemiştir. Makul sürenin belirlenmesinde somut olayın şartları, alıcının yanı sıra makul bir üçüncü kişinin o edimi ifa edebilmesi için gerekli olan süre de dikkate alınmalıdır ${ }^{124}$. CISG m. 64/II'de öngörülen makul süre, niteliği itibariyle bir hak düşürücü süredir. Dolayısıyla makul süre içerisinde satıcının sözleşmeyi ortadan kaldırma hakkını kullanmaması, hakkın kaybına yol açar. Ancak satıcının bu hakkını kaybetmesi; diğer haklarına, örneğin tazminat yahut aynen ifa talebine halel getirmeyecektir ${ }^{125}$. Makul süre, ilk durum açısından (m. 64/II-b-i) aykırılığın satıcı tarafından bilindiği ya da bilinmesi gerektiği zamandan itibaren; ikinci durum (m. 64/II-b-ii) bakımından ise ek sürenin bitmesiyle ya da alıcının ifa etmeyeceğini bildirmesiyle başlar.

\section{Sonuçları}

Sözleşme ilişkisi, sözleşmeyi ortadan kaldırma hakkının kullanılmasıyla birlikte bir tasfiye ilişkisine dönüşür ${ }^{126}$. Tasfiye ilişkisinin hüküm ve sonuçları CISG m. 81 ilâ 84. maddelerde düzenlenmiştir. Buna göre hakkın kullanılmasıyla birlikte taraflar, üstlendikleri; ancak henüz yerine getirmedikleri yükümlülükleri ifa etmekten kurtulur. İfası gerçekleşmiş edim ve yararların ise iadesi gerekecektir. Bunun dışında satıcının zararının karşılanması için CISG m. 74 uyarınca tazminat talep etmesi de mümkündür ${ }^{127}$.

124 Knapp, s. 473; Schwenzer/Schlechtriem, s. 1055; Yılmaz, s. 147.

125 Schwenzer/Schlechtriem, s. 1056.

126 Kanışlı (2016), s 493; Knapp, s. 468; Magnus, s. 431; Secretariat Commentary, s. 51; Schwenzer/Schlechtriem, s. 1290; Yelkenci, s. 163.

127 Yelkenci, s. 204. Birçok hukuk sisteminin aksine; Antlaşma, sözleşmenin ortadan kaldırma hakkının kullanılmasını, sözleşmeden doğan tüm hak ve yükümlülüklerin sona ermesi sonucuna bağlamamış (Vilus, s. 257); tazminat hakkının devamını sağlamıştır. Knapp, s. 468. 


\section{TAZMINAT TALEP ETME HAKKI}

Sözleşmenin alıcı tarafından ihlâli halinde başvurulabilecek yollardan bir diğeri, satıcının alıcıdan tazminat talebinde bulunmasıdır. Tazminat imkânıyla; alıcı yükümlülüklerini yerine getirmiş olsaydı satıcının içinde bulunacağı durum ile satıcının mevcut durumu arasındaki farkın giderilmesi amaçlanır ${ }^{128}$. Bu hak aynen ifa talebiyle birlikte kullanılabileceği gibi, sözleşmenin ortadan kaldırılması hâlinde de kullanılabilir ${ }^{129}$. Tazminat hakkına ilişkin düzenlemeler Antlaşma'nın 74 ilâ 77. maddelerinde yer almaktadır: 74. maddede tazminat talep etme hakkına ilişkin genel çerçeve çizilmiş; 75 ve 76. maddelerde sözleşmenin ortadan kaldırılması hâlinde tazminatın hesaplanmasına yönelik somut ve soyut yöntem belirtilmiş ${ }^{130} ; 77$. maddede ise zararı azaltma külfeti düzenlenmiştir.

Tazminat talep etme hakkına ilişkin olarak Antlaşma'da öngörülmüş iki temel ilke bulunmaktadır. İlki olan parayla tazmin ilkesine göre, satıc1, alıcıdan aynen tazmini talep edememekte; yalnızca nakden tazmin talebinde bulunabilmektedir ${ }^{131}$. Diğer bir ilke olan öngörülebilirlik ilkesine göre CISG m. 74/c.2 uyarınca ancak alıcının sözleşmenin kurulması aşamasında öngörebildiği zararlar talep edilebililir ${ }^{132}$.

${ }^{128}$ Kanışlı (2016), s. 494. Fark teorisinin kabul edildiğine ilişkin bkz. CISG-DK Görüşü, No: $6 ; \mathrm{m} .3,8$ ve 9 .

129 CISG m. 61/II’ye göre satıcı sözleşmeyi ortadan kaldırma hakkını kullanarak tazminat talep etme hakkından hiçbir şekilde vazgeçmiş olmaz. Schwenzer/Schlechtriem, s. 1058.

130 Magnus, tazminat, s. 292-293. Tazminatın hesaplama yöntemlerine ilişkin olarak CISG Danışma Kurulu, altı maddelik bir görüş hazırlamıştır. Bkz. CISG-DK Görüşü No. 8, CISG Madde 75 ve 76 Uyarınca Tazminatın Hesaplanması, 15 Kasım 2008, $<$ http://www.cisgac.com/file/repository/Turkish_No_8_SON.pdf> s.e.t. 03.04.201.

131 Erdem, s. 277; Magnus, tazminat, s. 290; Dayığlu, s. 78. Yâni, bazı hukuk sistemlerinin aksine, aynen tazmin yerine nakden tazmin prensibi kabul edilmiştir. Kanışlı (2016), s. 494; Winship, Peter 'Remedies Under The United Nations Sales Convention': Şıpka, Şükran/Yıldırım, Ahmet Cemil (Editörler) (2012) Yeni Türk Borçlar Kanunu ve CISG'e göre Satış Sözleşmeleri, İstanbul, On İki Levha, s. 220. Ayrıca CISG Danışma Kurulu'nun 6 nolu görüşüne göre, CISG m. 74 tam tazmin ilkesini yansıtmaktadır. Dayığlu, s. 71. Tazminatın kapsamı ve ispatına ilişkin çeşitli hususlar bu görüşte belirtilmektedir. Bkz. CISG-DK Görüşü No. 6, CISG Madde 74 Uyarınca Tazminatın Hesaplanması, 2006, <http://www.cisgac.com/file/repository/Turkish_No_6_SON.pdf> s.e.t. 03.04.2018. Zararın hesaplanmasına yönelik olarak "common law" sisteminin etkileri için bkz. Vilus, s. $247 \mathrm{vd}$.

132 Dayığlu, s. 77. 
Tazminat talep etme hakkının gündeme gelebilmesi için; (i) alıcının yükümlülüklerinden birini ihlâl etmesi, (ii) zararın ve (iii) ihlâl ile zarar arasında illiyet bağının bulunması gerekir ${ }^{133}$. Kusurdan bağımsız olan tazminat talep etme hakkında, ihlâlin esaslı bir ihlal olması aranmamaktadır. Antlaşma'da fiili zararların yanı sıra mahrum kalınan kârların da talep edilebileceği hükme bağlanmıştır ${ }^{134}$ (CISG m. 74; c. 1). Buna karşın doğrudan dolaylı zarar ayrımı yapılmamıştır; doktrinde her iki zarar türünün de talep edileceği kabul edilmektedir ${ }^{135}$. Neticede öngörülebilirlik ilkesinin çizdiği sınırları aşmayacak şekilde dolaylı zararlar da talep edilebilir.

Antlaşma'da tazminat talep etme hakkına yönelik çeşitli sınırlamalar öngörülmüştür. İlk olarak CISG m. 77’ye göre satıcı, alıcının sözleşmeyi ihlâl etmesi nedeniyle ortaya çıkan zararı azaltma külfeti altındadır. Satıcı, bu külfeti yerine getirmediği ölçüde, tazminat hakkını yitirir ${ }^{136}$. Alıcının CISG m. 79'a göre sorumluluktan kurtulması hâlinde, satıcı tazminat talebinde bulunamaz. Ayrıca CISG m. 80'e göre ihlâlin satıcının fiillerinden ya da ihmalinden kaynaklanması ve taraflar arasında bir sorumsuzluk antlaşmasının yapılmış olması hâlinde de alıcıdan tazminat talebinde bulunulamayacaktır.

\section{D. ÖZEL DURUMLAR}

Alıcının sözleşmeden ya da Antlaşma'dan kaynaklanan yükümlülüklerini ifa etmemesine ilişkin olarak Antlaşma'da öngörülmüş bazı özel durumlar bulunmaktadır. Bu kapsamda sırasıyla; CISG m. 71'de düzenlenen ifayı askıya alma hakkı, CISG m. 72'de düzenlenen alıcının ifa tarihinden önce sözleşmeyi esaslı şekilde ihlâl edeceğinin aşikâr olması, CISG m. 65'te düzenlenen satıcının malın özelliklerini belirleme hakkı ve CISG m. 73'te düzenlenen art arda teslimli sözleşmelerde sözleşmeyi ortadan kaldırma hakkına ilişkin durumlar incelenecektir.

\footnotetext{
Erdem, s. 281-282; Kanışlı (2016), s. 495.

Magnus, tazminat, s. 291.

Kanışlı (2016), s. 495.

36 Vilus, s. 251.
} 


\section{1. İfayı Askıya Alma Hakkı}

Alıcının sözleşmeden ya da Antlaşma'dan kaynaklanan yükümlülüklerini ifa etmemesine ilişkin özel durumlardan ilki CISG m. 71'de düzenlenen ifayı askıya alma hakkıdır. Satıcı, alıcının yükümlülüklerinin esaslı bir kısmını ifa etmeyeceğinin anlaşılması durumunda, şartların varsa kendi yükümlülüklerinin ifasını askıya alabilir ${ }^{137}$. Bu yola başvurmasıyla birlikte, satıcının kendi yükümlülüklerini ifa etmemesi, artık bir sözleşmeye aykırılık durumu oluşturmayacaktır ${ }^{138}$.

İfayı askıya alma hakkının kullanılabilmesi için Antlaşma'da belirlenen iki durumdan birinin varlığı gerekir ${ }^{139}$. Buna göre ilk olarak alıcının ifa veya ödeme kabiliyetindeki ciddi bir yetersizlik (serious deficiency) nedeniyle, yükümlülüklerinin esaslı bir kısmının ifa edilmeyeceğinin anlaşılması durumunda, satıcının kendi yükümlülüklerinin ifasını askıya alma hakkı bulunmaktadır. Diğer durum ise alıcının ifaya hazırlığı yahut ifası esnasındaki davranışları nedeniyle yükümlülüklerinin esaslı bir kısmının ifa edilmeyeceğinin anlaşılması hâlidir; satıcı bu durumda da kendi yükümlülüklerinin ifasını askıya alabilir.

İfayı askıya alma hakkını kullanmak isteyen satıcının, bu durumu derhal alıcıya bildirmesi gerekir (CISG m. 71/III). Bildirimde alıcidan sözleşmeyi ifa edeceğine dair yeterli teminat göstermesi talep edilir; teminatın gösterilmesi durumunda satıcı ifaya devam etmek zorundadır; yükümlülüklerini askıya alamaz.

İfayı askıya almaya sebebiyet veren durumlardan birinin çıkmasından önce, satıcının malları göndermiş olması durumunda, satıcı şartların varlığ 1 halinde ifayı askıya alma hakkına dayanarak malların alıcıya verilmesini engelleyebilir (CISG m. 71/II). Alıcının elinde, kendisine bu malları edinme hakkı veren bir belgenin bulunması da sonucu etkilemeyecektir.

Satıcının kendi yükümlülüklerini askıya alması, alıcıdan tazminat talep etme hakkını engellememektedir ${ }^{140}$. Satıcı bu durumda dâhi CISG m. 74'e dayanarak zararlarının tazmin edilmesini talep edebilir.

Erdem, s. 277; Vilus, s. 242.

Kanışlı (2016), 497.

140 Kanışlı (2016), s. 497. 


\section{Alıcının İfa Tarihinden Önce Sözleşmeyi Esaslı Şekilde İhlâl Edeceğinin Aşikâr Olması}

Sözleşmeyi ortadan kaldırma hakkı, kural olarak ihlâlden sonra kullanılabilir. Ancak CISG m. 72'deki düzenleme uyarınca, sözleşmeyi ortadan kaldırma hakkının ihlâlin fiilen gerçekleşmesinden önce de kullanılabilmesi mümkündür. Buna göre alıcının kararlaştırılan ifa tarihinden önce sözleşmeyi esaslı şekilde ihlâl edeceğinin aşikâr olması durumunda satıcı sözleşmeyi ortadan kaldırabilirir ${ }^{141}$.

Satıcının, ifa zamanından önce sözleşmeyi ortadan kaldırabilmesi için her şeyden önce gerçekleşecek ihlâl riskinin esaslı olması gerekir. Hakkın kullanımına ilişkin bir diğer şart ise ihlâlin gerçekleşeceğinin aşikâr olmasıdır. Kararlaştırılan ifa zamanından sonra ihlâl gerçekleşseydi, satıcı sözleşmeyi ortadan kaldırma hakkına sahip olacak idiyse, bu durumda ihlâlin gerçekleşeceğinin aşikar olmasından ve dolayısıyla CISG m. 72'nin uygulanmasından söz edilir ${ }^{142}$. İfa zamanından önce sözleşmeyi ortadan kaldırma hakkının kullanılabilmesi için bir diğer şart ise satıcının süre elverdiği takdirde karşı tarafa, yükümlülüklerinin ifasına dair yeterli teminat göstermesine imkân sağlamak amacıyla bildirimde bulunmasıdır. Ancak karşı tarafın, yükümlülüklerini ifa etmeyeceğini beyan etmesi hâlinde böyle bir bildirimde bulunmaya ihtiyaç yoktur ${ }^{143}$ (CISG m. 72/III).

\section{Satıcının Malın Özelliklerini Belirleme Hakkı}

Sözleşme uyarınca malın şeklinin, ölçüsünün ve diğer niteliklerinin belirlenmesi alıcıya bırakılabilir. Bu durumda alıcının, malı teslim alma yükümlülügüünu bir parçası olarak ${ }^{144}$ malın niteliklerini belirlemesi gerekmektedir. Malın niteliklerinin alıcı tarafından belirlenmesi, aynı zamanda aynen ifa talebinin yerine getirilmesini de kolaylaştırır.

141 Sözleşmeyi ortadan kaldırma hakkını sağlayan bu durum için Anglosakson hukukunda "beklenen ihlâl" (anticipatory breach) kavramı kullanılmaktadır (Jenkins, s. 413). Türk doktrininde bu durum, "öne alınmış sözleşme ihlali" olarak çevrilmiştir (Bkz. Kanışlı (2016), s. 498); ancak kanaatimizce çevirinin doğrudan müessese ismi olarak değil; CISG $\mathrm{m}$. 72'nin unsurları vasıtasıyla yapılması daha isabetli olacaktır. Madde hükmünden hareketle "alıcının ifa tarihinden önce sözleşmeyi esasl şsekilde ihlâl edeceğinin aşikâr olması" ifadesinin kullanılması gerektiğini düşünmekteyiz.

142 Erdem, s. 276-277; Jenkins, s. 414; Kanışlı (2016), s. 498.

143 Vilus, s. 246.

144 Zeytin, s. 260; Kanışlı (2016), s. 499; Örneğin alıcı 1 Nisan tarihinde, 1 Ekim’den önce teslim edilecek şekilde satıcıdan 1000 çift ayakkabı siparişi vermiş olabilir. Yapılan 
Kararlaştırılmasına rağmen alıcının malın niteliklerini belirlememesi durumunda satıcı, diğer seçimlik haklarının yanı sıra CISG m. 65'e dayanarak malın niteliklerini bizzat belirleme hakkını kullanabilecektir. Satıcının malın niteliklerini belirleyebilmesi için Antlaşma'da iki kümülatif şart öngörülmüştür. İlk olarak taraflar arasındaki sözleşmeyle malın özelliklerinin alıcı tarafından belirleneceğinin kararlaştırılması gerekir ${ }^{145}$. İkinci olarak alıcının, belirlenen bu yükümlülügü kararlaştıılan tarihte veya satıcının kendisine bu yöndeki talebinin ${ }^{146}$ ulaşmasından itibaren makul bir süre içinde yerine getirmemiş olması gerekir ${ }^{147}$. Bu durumda satıcı, sahip olduğu diğer haklara halel gelmeksizin alıcının, satıcı tarafından bilinebilecek ihtiyaçlarına göre, malların özelliklerini tek taraflı olarak belirleyebilecektir. Belirlenen özelliklerin her iki taraf açısından hüküm ve sonuç doğurabilmesi için, CISG m. 65/II uyarınca bunların alıcıya bildirilmesi ve ona aksi yönde bir belirleme yapabilmesi için makul bir sürenin tanınması gerekir. Belirlenecek makul sürenin, alıcının ihtiyaçları dikkate alınarak ona malın özelliklerini belirleme imkânı sağlayacak bir süre olması gerekmektedir ${ }^{148}$.

Makul süre içinde, alıcının satıcınınkinin aksine bir belirleme yapmaması durumunda, satıcı tarafından belirlenen özellikler her iki taraf bakımından da bağlayıcı olacaktır. Dolayısıyla makul sürenin bitiş anından itibaren alıcının, malın nitelik ve özelliklerini belirleme hakkı tümüyle sona erer. Buna karşılık alıcının, makul süre içerisinde farklı özellikler belirlemesi durumundaysa alıcının belirlediği özellikler, her iki taraf açısından bağlayıcı olacaktır $^{149}$.

sözleşmede alıcının, satıcıya 1 Eylül'e kadar ayakkabıların stillerini ve büyüklüklerini bildireceği kararlaştırılmış olabilir. Knapp, s. 477. Bu durumda alıcının malın özelliklerini belirlemesi, malı teslim alma yükümlülüğünün bir parçasıdır.

Sert, s. 236; Schwenzer/Schlechtriem, s. 1062; Zeytin, s. 261.

Satıcının talebini içeren irade beyanı, niteliği itibariyle varması gerekli bir irade beyanıdır. Madde hükmünde geçen "ulaşmasından itibaren" tabiri, açık bir şekilde CISG m. 27'nin uygulanmayacağı anlamına gelmektedir. Schwenzer/Schlechtriem, s. 1063. Zeytin, s. 261

Knapp, s. 477; Schwenzer/Schlechtriem, s. 1063. Sert, s. 236.

Knapp, s. 478. Malın teslim tarihi yaklaştıkça, makul sürenin de kısalması gerekir. Zeytin, s. 261. Alıcının malın özelliklerini belirleyen irade açıklaması, gönderme anından itibaren hüküm ve sonuçlarını doğurur. Zeytin, s. 261. 


\section{Art Arda Teslimli Sözleşmeler Açısından Sözleşmeyi Ortadan Kaldırma Hakkı}

Alıcının yükümlülüklerini yerine getirmemesine ilişkin özel durumlardan bir diğeri de art arda teslimli sözleşmeler açısından ihlâlin meydana gelmesidir ${ }^{150}$. CISG m. 73'e göre art arda teslimin kararlaştırıldığı bir sözleşmede, alıcının belirli bir teslimata özgü yükümlülüklerini ifa etmemesinin esaslı bir ihlâl teşkil etmesi durumunda, kural olarak satıcının yalnızca o teslimata yönelik olarak sözleşmeyi ortadan kaldırma hakkı bulunmaktadır. Ancak o teslimata ilişkin yükümlülüklerden birinin ihlâl edilmiş olması, gelecekte gerçekleştirilecek teslimatlara yönelik olarak esaslı ihlâl oluşturma konusunda ciddi bir risk taşıyorsa, satıcı makul bir süre içerisinde sözleşmeyi geleceğe etkili olacak şekilde ortadan kaldırabilir (CISG m. 73/II). Son olarak o teslimata özgü ihlâlin, geçmişte yapılan teslimatları etkilemesi halinde, sözleşme geçmişe etkili olarak da ortadan kaldırılabilecektir (CISG m. 73/III)

\section{SONUÇ}

1 Ağustos 2011'den bu yana Türk Hukukunun yürürlük kaynaklarından biri olan Viyana Satım Antlaşması'na göre alıcının yükümlülükleri; semenin ödenmesi, malın teslim alınması ve diğer yükümlülüklerin yerine getirilmesinden ibarettir. Bu yükümlülüklerin ihlâli halinde satıcının hangi haklara sahip olduğunu ihlâlin türü değil derecesi, yani esaslı olup olmadığı belirler. Zirâ Antlaşma'nın ifa engellerine yönelik bütüncül bakış açısı bu sonucu zorunlu kılmaktadır. Neticede esaslı olmayan ihlâl durumunda satıcı, aynen ifayı talep etme ve tazminat talebinde bulunma haklarına sahipken; esaslı ihlâlin bulunması durumunda ise sözleşmeyi ortadan kaldırma hakkını da doğrudan kullanabilmektedir.

Alıcının yükümlülükleri açısından yapılan asli - diğer yükümlülükler ayrımıyla, esaslı ve esaslı olmayan ihlâl ayrımı birbiriyle örtüşmemektedir. Bir başka deyişle asli yükümlülügün ihlâli her zaman için esaslı bir ihlâle vücut vermeyeceği gibi, kimi zaman diğer yükümlülüklerden birinin ihlâli ise esaslı bir ihlâl teşkil edebilir.

150 Jenkins, s. 419; Kanışlı (2016), s. 499; Knapp, s. 471; Vilus, s. 246. 
Antlaşma kapsamında alıcıya yükümlülüklerini yerine getirmesi amacıyla, ek süre tanınabilir. Esaslı olmayan bir ihlâlin varlığı durumunda, tanınan ek sürenin sonuçsuz kalmasıyla ihlâl, adeta esaslı bir ihlâle dönüşmektedir. Ancak bu dönüşüm, yalnızca ihlâlin sonuçları bakımından geçerlidir. Yani ek süre örneğin esaslı olmayan ihlâlde de sözleşmeyi ortadan kaldırma hakkının kullanılmasına imkân sağlar. Yoksa esaslı olmayan bir ihlâl, ek sürenin tanınmasıyla birlikte teknik anlamda esaslı ihlâle dönüşmez.

Sözleşmeyi ortadan kaldırma hakkına ilişkin önemli problemlerden birisi de terminolojidir. Antlaşma'nın ifa engellerine bütüncül bir bakış açısıyla yaklaşması ve "avoidance"ın sınırlarının Türk/İsviçre hukukundaki "dönme"nin sınırlarından daha geniş olması nedenleriyle bu müessesenin "dönme hakkı" yerine "sözleşmeyi ortadan kaldırma hakkı" olarak ifade edilmesinin daha isabetli olduğu kanaatindeyiz.

Son olarak sözleşmeyi ortadan kaldırma hakkının sınırlanması hâllerine ilişkin olarak doktrindeki hâkim görüşün aksine, geç ifa durumunun gerçek anlamda bir sınırlama teşkil etmediği kanaatindeyiz. Zira normal şartlarda gecikmiş de olsa ifanın ardından satıcının sözleşmeyi ortadan kaldırma hakkını kullanamaması gerekirken, CISG m. 64/II-a hükmü gereğince satıcı, geç ifayı öğrenmeden önce bu hakkı kullanabilmektedir. Dolayısıyla hakkın kullanılmasına ilişkin zaman aralığı daraltılmamakta, aksine genişletilmektedir. 


\section{KAYNAKÇA}

Akipek Öcal, Şebnem; 'Türk Hukuku Açısından Viyana Satım Sözleşmesi': Temel, Erhan (Editör) (2015) Viyana Satım Sözleşmesi Hukuku ve Tüketici Hukuku, Ankara, Adalet.

Atamer, Yeşim (2008) Satıcının Sözleşmeye Aykırı Davranışı Ekseninde CISG’ın İfa Engelleri Sistemine Genel Bakış: Milletlerarası Satım Hukuku, İstanbul, On İki Levha.

Başoğlu, Başak; 'Milletlerarası Mal Satımına İlişkin Sözleşmeler Hakkında Birleşmiş Milletler Antlaşması Uyarınca Aynen İfa ve Bunun Tarihsel Arka Planı': Okur, Sinan (Editör) (2016) Milletlerarası Mal Satım Hukuku, Ankara, Adalet.

Bortolotti, Fabio (2006) 'Remedies Available to the Seller and Seller's Right to Require Specific Performance (Articles 61, 62 and 28)' Journal of Law and Commerce, Cilt: 25, Say1: 1, s. 335-338.

Chengwei, Liu (2004) 'Comparison of CISG Article 45/61 remedial provisions and counterpart PECL Articles 8:101 and 8:102' Guide to Article 45, <http://cisgw3.law.pace.edu/cisg/text/peclcomp45.html>s.e.t. 29.06.2018.

CISG-DK Görüşü No. 6, CISG-DK Görüşü No. 6, CISG Madde 74 Uyarınca Tazminatın Hesaplanmas1, 2006, <http://www.cisgac.com/file/repository/Turkish_No_6_SON.pdf> s.e.t. 29.06.2018.

CISG-DK Görüşü No. 8, CISG Madde 75 ve 76 Uyarınca Tazminatın Hesaplanmasi, 15 Kasım 2008, <http://www.cisgac.com/file/repository/ Turkish_No_8_SON.pdf> s.e.t. 29.06.2018.

CISG-DK Görüşü No. 9, Sözleşmeden Dönmenin Sonuçları, 15 Kasım 2008, <http://www.cisgac.com/file/repository/Turkish_No_9_ SON.pdf $>$ s.e.t. 29.06.2018.

CISG-DK Görüşü; No. 11, Alıcının Ödeme Borcu Kapsamında CISG Uyarınca Belgelerden Doğan Sorunlar, 03 Ağustos 2012, <http://www.cisgac.com/file/repository/Turkish_No_11_SON.pdf> s.e.t. 29.06.2018. 
CISG-DK Görüşü; No. 14, CISG Madde 78 Uyarınca Faiz, 21 Ekim 2013, <http://www.cisgac.com/file/repository/Turkish_No_14_SON.pdf> s.e.t. 29.06 .2018 .

Dayıoğlu, Yavuz (2011) CISG Uygulamasında Sözleşmenin İhlali Halinde Alıcının Hakları ve Özellikle Alıcının Tazminat Talep Etme Hakkı, İstanbul, On İki Levha.

Duncan, John C. (2000) 'Nachfrist Was Ist? Thinking Globally and Acting Locally: Considering Time Extension Principles of the U.N. Convention on Contracts for the International Sale of Goods in Revising the Uniform Commercial Code' Brigham Young Law Review, s. 1363-1411.

Eren, Fikret (2017) Borçlar Hukuku Genel Hükümler, 21. Baskı, Ankara, Yetkin.

Erdem, Ercüment (2013) 'Viyana Satım Antlaşması'na Göre Alıcı ve Satıcının Borçlarının İhlalinin Sonuçları ve Türk Hukuku ile Karşılaştırılması' Galatasaray Üniversitesi Hukuk Fakültesi Dergisi, Sayı: 1, s. 259-288.

Flechtner, Harry M. (1988) 'Remedies Under the New International Sales Convention: The Perspective from Article 2 of the U.C.C.' Journal of Law and Commerce, Cilt 8, s. 53-108.

Huber, Peter/Mullis, Alastair (2007) The CISG: A New Textbook for Students and Practitioners, München, European Law Publishers.

Jenkins, Sarah H. (2013) 'Rejection, Revocation of Acceptance, and Avoidance: A Comparative Assessment of UCC and CISG Goods Oriented Remedies' Minnesota Journal of International Law, Cilt: 22, Sayı: 152, s. 150 .

Iş̧ıntan, Pelin (2013) 'Uluslararası Satım Sözleşmelerine İlişkin Birleşmiş Milletler Antlaşması ve Borçlar Kanunu Düzenlemelerinde Aynen İfa Kavramı' Galatasaray Üniversitesi Hukuk Fakültesi Dergisi, Sayı: 1, s. 161-181.

Kanışlı, Erhan (2013) CISG Uyarınca Alıcının Yükümlülükleri ve Sözleşmeye Aykırılık Halinde Satıcının Hakları, İstanbul, On İki Levha.

Kanışlı, Erhan; 'CISG Uyarınca Alıcının Sözleşmeye Aykırılığı Halinde Satıcının Hakları’: Okur, Sinan (Editör) (2016) Milletlerarası Mal Satım Hukuku, Ankara, Adalet. 
Karollus, Martin (1995) 'Judicial Interpretation and Application of the CISG in Germany 1988-1994' Cornell Review of the Convention on Contracts for the International Sale of Goods, s. 51-94.

Kaya, Cansu (2012) CISG Gereğince Alıcının Satım Bedelini Ödeme Borcu, İstanbul, On İki Levha.

Kee, Christopher/Munoz, Edgardo (2009) 'In Defence of The CISG' Deakin Law Review, Cilt: 14, Say1: 1, s. 99-123.

Koch, Robert (1998) 'The Concept of Fundamental Breach of Contract under the United Nations Convention on Contracts for the International Sale of Goods (CISG)' Pace Review of the Convention on Contracts for the International Sale of Goods, s. 177-354.

Knapp, Victor 'Article 61-65': Bianca-Bonell (Editör) (1987) Commentary on the International Sales Law, Milan, s. 442-482.

Magnus, Ulrich (2005) 'The Remedy of Avoidance of Contract Under CISG - General Remarks and Special Cases' Journal of Law and Commerce, Haziran, Sayı: 25, s. 423-436.

Sarıkaya, Murat (2017) CISG Kapsamında Sözleşmenin Esaslı İhlali, İstanbul, Filiz.

Schwenzer/Schlechtriem (2015) Milletlerarası Mal Satımına İlişkin Sözleşmeler Hakkında Birleşmiş Milletler Antlaşması (Viyana Satım Sözleşmesi) Şerhi, İstanbul, On İki Levha.

Secreteriat Commentary (1978) Commentary on the Draft Convention on Contracts for the International Sale of Goods, UN DOC. A/CONF. $97 / 5$.

Sert, Selin (2013) Viyana Satım Sözleşmesinde (CISG) İfa Engelleri ve Sonuçları, İstanbul, Vedat.

Sevon, Leif (1990) 'Obligations of the Buyer under the Vienna Convention on the International Sale of Goods' Suomalainen Lakimiesten Yhdistys: - Tidskrift utgiven av Juridiska Föreningen i Finland, Cilt 126, s. 327-343. 
Schlectriem, Peter (2006) 'Subsequent Performance and Delivery Deadlines - Avoidance of CISG Sales Contracts Due to Non-conformity of the Goods' Pace International Law Review, Sayı: 1, s. 83-98.

Toker, Ali Emrah (2014) 'Viyana Satım Sözleşmesi (CISG) Uyarınca Sözleşmenin Esaslı İhlâli’ Milletlerarası Hukuk ve Milletlerarası Özel Hukuk Bülteni, Cilt: 33, Sayı: 1, s. 213-250.

Vilus, Jelena (1986) 'Provisions common to the obligations of the seller and the buyer' International Sale of Goods: Dubrovnik Lectures, Occena, s. 239-264.

Viscasillas, Pilar Perales (2005) 'The Nachfrist Remedy' Celebrating Success: 25 Years United Nations Convention on Contracts for the International Sale of Goods, Singapore, s. 89-102.

Winship, Peter 'Remedies Under The United Nations Sales Convention’ : Şıpka, Şükran/Yıldırım, Ahmet Cemil (Editörler) (2012) Yeni Türk Borçlar Kanunu ve CISG’e göre Satış Sözleşmeleri, İstanbul, On İki Levha.

Yelkenci, Işıl (2014) Milletlerarası Mal Satımına İlişkin Sözleşmeler Hakkında Birleşmiş Milletler Antlaşması (CISG) Uyarınca Alıcının Sözleşmeden Dönmesi, İstanbul, On İki Levha.

Yılmaz, Süleyman (2013) Milletlerarası Mal Satımına İlişkin Sözleşmeler Hakkında Birleşmiş Milletler Antlaşması (CISG) Uyarınca Sözleşmenin İhlali Halinde Alıcının Hakları, Ankara, Yetkin.

Zeytin, Zafer (2015) Milletlerarası Satım Sözleşmeleri HukukuCISG, 2. Baskı, Ankara, Seçkin. 